\title{
Shall the Religious Inherit the Earth?: Demography and Politics in the Twenty-First Century
}

\author{
Eric Kaufmann, Belfer Center, Harvard University/Birkbeck College, University of \\ London e.kaufmann@bbk.ac.uk
}

Introduction

Most observers accept that the aftermath of the Cold War did not lead to Francis Fukuyama's liberal democratic World Order based on the 'End of History', but rather to the emergence of new forms of conflict based on religion and ethnicity. At the same time, over 90 percent of violent conflicts take place within states rather than between them. Even where violence is rare - as in the advanced West - questions of ethnic and religious conflict are increasingly dominating the agenda. Even so, Fukuyama's cosmopolitan liberalism is not dead, but seems in the ascendant in much of the developed world: politicians increasingly fight elections on the basis of managerial competence rather than transformative ideologies, and people have become more liberal, more secular and more tolerant of diversity. Perhaps it is just a matter of time before the developing world catches up, as Fukuyama suggested.

Against such an optimistic view, this paper claims that the developing world will not only never catch up, but that, ironically, it is the West which will increasingly come to resemble the developing world. Committed religious populations are growing in the West, and will reverse the march of secularism before 2050. The logic which is driving 
this apparently anti-modern development is demography, a shadowy historical force whose power multiplies exponentially with the modernisation process. Demography is about raw numbers, and, in an age of low mortality, its chief components are fertility and migration.

Demography often played a signal role in determining the direction of social and political change in the past. Migrations of Celts displaced Basque-speaking cultures in Europe, and Teutons in turn replaced Celts; Uneven death rates from the Great Plague altered the balance of power between East and West; Growing populations outstripping available resources were a major force behind European Revolutions in 1688, 1789 and 1917; and high Amerindian mortality from disease greatly eased the task of white settlement in the Americas.

Demography is about numbers, hence any development which makes numbers count more for politics will magnify the social power of demographic change. The French Revolution is viewed as the curtain-raising event of the modern period. Its tenets were liberty, equality, democracy and the nation-state. Over the nineteenth and twentieth centuries, western states increasingly refined these concepts, extending the franchise, expanding the scope of toleration and implementing a social welfare state to cover everwider strata of the population. All of these forces amplify the importance of demography.

When resources and power are monopolised by an autocrat or dominant group, the rest of the population can grow exponentially without affecting politics. The growth of the Indian masses under the British raj, Shi'ites in Baathist Iraq, or Hutus in Burundi is simply meaningless when the dominant minority controls power and the masses lack a clear sense of nationalism. On the other hand, once the masses are ushered into history by 
nationalist mobilisation and a divine, often foreign, ruler loses legitimacy through democratisation, demography rears its head. Majorities are no longer content to be ruled by minorities. After nationalist revolution, when the vote is introduced, numbers become everything since the majority gets to form the government. In Iraq, Shi'ites replace Sunnis at the apex of power. In ethnically-divided societies like Kenya or Uganda, elections become a form of ethnic census-talking, and politicians exhort their supporters to reproduce at faster rates.

Constitutional liberty and democracy have long histories in the core nations of the West, but it is only very recently, in the post-1945 or even post-1960s period, that the logic of liberty and equality has unfolded in the cultural and social sphere. First, welfare state provision expanded significantly, increasing the resources which citizens could claim upon entering a country through birth or migration. Second, the 'cultural turn' of the Left in the 1960s opened up modern nations to non-traditional sources of immigration. To bar nonwhites from Europe and its offshoots was seen to run counter to the tenets of cultural equality. To greatly restrict immigration was to act in an illiberal manner. In other words, the logic of liberty and equality demanded an openness to global demographic currents. This empowered demography as a history-making force in the West, though not in East Asia or the Persian Gulf oil regimes, where demography remained strictly controlled.

Improvements in trans-national communications and transport have created a global demographic system. Not long ago, populations could expand and contract in India or Africa with few consequences for Europe, Japan or North America. Now, more of the world's residents are aware of the riches of the developed world, north-south kinship 
networks are better, and transportation to the north is more rapid. Uneven trends in population growth between different parts of the world become linked by the strands of globalisation. This expands the scope of demographic supply and concentrates it on developed societies, further amplifying the power of demography in our time.

Liberty, equality, democracy, nationalism: these forces have removed our demographic insulation, causing demographic change to become telescoped within the states of the developed world. Even more remarkable is that this is occurring at a moment of global demographic upheaval caused by falling mortality and fertility. The world's demographic transition is extremely rapid and highly uneven. In the developed world, populations are aging and declining. In the developing world, they are youthful and rising. Globalisation links these dynamics together into one system, placing enormous demographic pressure on the developed world.

Yet the peaceful reality of the West should give us pause. The West has not cracked under the pressure, and the most important reason has been the salutary effect of liberalism and equality in changing the xenophobic attitudes of dominant ethnic groups. Liberalism and equality are therefore double-edged: they have exposed the West to demographic instability, but have also allowed it to dissipate the pressures of immigration through cosmopolitanism. Inter-racial and inter-religious marriage rates have been rising along with more tolerant social attitudes to homosexuality, pornography, the family and lifestyle. Many of the descendants of the European immigrant flows of the nineteenth and twentieth centuries have assimilated in North America and northwestern Europe. Many Asians, Latin Americans and Afro-Caribbeans also seem to be intermarrying with native white populations and assimilating to host cultures at a steady rate. 
Looking South, we find more positive news in the form of plunging total fertility rates. China's fertility is lower than the West's. Parts of India, Latin America and North Africa, not to mention Turkey and Iran, have reached below-replacement fertility. In the long-term, as long as economies develop, demographic pressure from the South will ease and populations will age. Finally, improvements in technology (such as biometric id cards and surveillance) will allow the West to control unwanted immigration and prevent it from reaching undesirable levels.

This book accepts that there is at least an even chance of success for the positive scenario. This despite the fact that the South's demographic transition could take over a century to reach parts of sub-Saharan Africa and some seemingly transition-resistant Muslim societies like Yemen. Immigration controls will ensure that the South will not swamp the North, as feared by the racial apocalyptic Jean Raspail in his dystopic novel, The Camp of Saints. Ethnic majorities will certainly become browner in Europe and North America through inter-racial marriage, but the porous nature of dominant groups should allow assimilation to counter the zero-sum nature of a changing ethnic composition. Demographic pressure is intense and will only become stronger in our century, but the liberalism of host societies seems sufficient to dissipate this energy. Let us make the bold assumption that white flight and the rise of the far right are momentary phenomena and that younger generations will be more comfortable with higher levels of ethnic diversity, accepting racial 'browning' through intermarriage more readily.

Yet, even if ethnic tensions can be managed and dominant-group liberalism holds, we have a problem. What if some minorities carry a cultural gene which allows them to resist assimilation? What if they refuse to be killed with kindness, but view modern 
liberalism as a deadly threat to their most cherished values? No matter how liberal the dominant group, it takes two to tango. Assimilation-proof sub-groups can thwart the majority's corrosive liberal-cosmopolitanism, allowing demographic pressure to build up. Resistant minorities with high fertility and/or immigration rates can act as conveyor belts for demographic change, serving as an entry point for global demographic instability to influence First World politics.

What then might innoculate ethnic groups against the charms of western liberal assimilation? The late Ernest Gellner, a prominent theorist of nationalism, coined the term 'counter-entropic' to describe the traits which help prevent ethnic minorities from being washed away by assimilation. Certainly race, once viewed as an insuperable barrier, is nothing of the kind, having been strongly breached by intermarriage in the late twentieth century. The case is different with religion. Gellner cited religion as the archetypal counter-entropic trait, and was thinking of the Jews of Europe. Jewish religious practice varies immensely, of course, and many Jews were open to secularisation and, eventually, mixed marriage. But literalist religion is a much tougher adversary. Ethnicity and race may succumb to liberal modernity, but committed religious populations cannot be assimilated to liberal secularism fast enough to compensate for their demographic advantage in a world of plunging fertility and growing migration. In the end, it is a battle between religious fertility on the one hand, and, on the other, religious decline through the 'assimilation' of religious offspring into secularism. This paper argues that the weakness of secularism and a widening secular-religious fertility gap points toward a religious victory. 
We are reaching a critical moment in history. Globally, human fertility is declining. The convulsions will be felt most keenly in the West, but eventually the current demographic revolution will reach much of the planet. Like a falling global water table, populations will first begin to decline in the West, then in East Asia, South Asia, North Africa, the Middle East and finally, sub-Saharan Africa. As population shrinks in one place, flows from elsewhere may replenish its stocks (if it has the wealth to attract them, as in America), but the final result will be a human population on its way to extinction. This is a fear voiced by neoliberal writers like Ben Wattenberg and Philip Longman, who question why humanity has lost the will to reproduce itself. (Wattenberg 2005; (Longman 2005) Maybe we are victims of our own success in circumventing our human biology and its evolutionary drives? Could it be that 'through the introduction of modern contraception, the evolutionary link between the drive for sex and procreation has been broken and now reproduction is merely a function of individual preferences and culturally determined norms.' (Lutz, Skirbekk et al. 2006: 8)

The population declinists have a powerful point, but human population will not dwindle to zero, precisely because of the 'counter-entropic' religiously-committed populations whose fertility remains above replacement even in societies experiencing general population decline. The water table may be falling, but there are important religious wellsprings, and these will become increasingly apparent. Ultra-Orthodox Jews, whether in Israel, Europe or North America, have a two or threefold fertility advantage over their liberal-Jewish counterparts. Their eventual achievement of majority status within worldwide Jewry in the twenty-first century seems certain. Evangelical and neotraditional Christians in the United States and, increasingly, in Europe will follow suit. 
Islamist Muslims and traditionalists of other faiths are not far behind. Their expansion will eventually be sufficient to counter worldwide population decline.

This process comes to fruition in a modern, urban age. Those who are fertile and religious simply because their parents and neighbours were (consider rural Uganda or Kurdistan) are living in a traditional society. These societies are in rapid decline as urbanisation and communication introduce modern ideas and technologies like birth control. Fertility and religiosity may decline as traditionalists encounter modernity, but some traditionalists will choose to resist religious decline and sign up to religious movements, many of which are fundamentalist. Most see little point in liberal religiosity: if one is liberal and modern, religion is an anachronism. Even if the parents retain a religious link, the children, or their children, will eventually secularise. On the other hand, if one chooses religion, one rejects a large chunk of modern liberalism's core message. Thus it makes sense to go for the strong stuff. In the United States, as in Europe and Israel, the religious centre is hollowing out as secularists and fundamentalists expand on its theological flanks.

Committed religious populations in the modern age are innoculated against secularisation by their anti-liberal outlook. Moderate Jews, Christians or Muslims viewed religion as a part of a wider, inherited, social package. Most were able to unconsciously slide into secularism as their societies changed. In contrast, their fundamentalist offshoots have become self-consciously anti-secular, defining themselves against the secular humanist threat and mobilising against it. High fertility and family values are counterpoised to the individualism and low fertility of the secular majority. A parallel can be seen in the rise of modern minority nations like the Welsh or Irish, who became self- 
conscious of their identity when their linguistic cultures had declined beyond the point of viability. When they all spoke Welsh or Irish, they didn't think about it and were not nationally conscious, so were susceptible to assimilation into English. Only once they had lost their language did they become self-conscious. Irish and Welsh nationalists tried to revive their languages, but success eluded the Irish and is difficult for the Welsh.

Fundamentalist religious sects are in a much healthier position than most linguistic nationalists. They have achieved self-consciousness while they still have a solid core of adherents. They also have high fertility and are poised for demographic growth. They seem certain to increase as a proportion of the national population in many parts of the world.

Religious fertility is only part of the story behind religious growth. The other side of the equation is the decline in the power of secularism to seduce the children of the religious to its message. Secularism succeeded as a social and political movement in the post-1789 period because of its emotional appeal rather than its rational criticism of religious dogma. The great secular religions of nationalism, socialism, and - to some degree - 1960s cultural anarchism, promised glorious Utopian futures in which secular intellectuals were guaranteed a guiding role. They promised identity, power, wealth and freedom to the masses. Often they were explicitly anti-clerical, as with Italian or French nationalism and Soviet socialism.

After the upheavals of the 1960s, much of the enthusiasm behind transformative politics ebbed away. The 'End of Ideology', already proclaimed in 1960 by Daniel Bell, became a political reality in 1989. Popular intellectual movements like post-modernism began to criticise the entire project of western secular modernity in favour of cultural 
relativism. The principle of tolerating and 'celebrating' diversity is a corollary of postmodern relativism which opens up space for antimodern religious 'diversities' to take root. If they are demographically-powerful religious movements like Islamism or evangelical Chrisianity, they will exploit this weakness to progressively erode the hegemony of western secular humanism.

The eclipse of nationalism and the celebration of cultural diversity have created a moral climate in which religious fervour is more acceptable than ethnic exclusion. In the United States, the ethnic cleavage of politics in the northern states which divided native Protestants from heavily urbanised Catholics and Jews began in the 1830s and persisted until the fall of the Democratic alignment of 1968. Since then, unprecendented alliances have formed across the Protestant-Catholic-Jewish and even Muslim divides. As Robert Wuthnow remarked in 1989, 'the major divisions in American religion now revolve around an axis of liberalism and conservatism rather than the denominational landmarks of the past'. (Wuthnow 1989) American conservative thinkers no longer stress ethnic issues like immigration and national identity, but rather religious ones like family values, abortion, gay rights, stem cell research and school prayer. Relatively secular immigration restrictionists like Pete Wilson find themselves confronting the Republican party elite and Christian Coalition, who have opened their doors to Latino and Asian evangelicals and their concerns. As is clear from the vexed issue of illegal Mexican immigration, elite conservatives are strenuously trying to downplay ethnic issues in favour of the more ecumenical cause of religio-moral politics.

In the Europe of tomorrow, immigration and religious fertility will increase the proportion of committed Muslims and Christians, many from the developing world. It 
may seem fanciful to imagine a moral conservatism uniting white and nonwhite Christians as well as Muslims against 'secular humanists'. However, a version of this process has occurred in the United States, and it can be argued that the cocktail of cultural relativism, secular exhaustion and demographic change is even more potent in Europe than America. The division between native ethnic groups and immigrant groups is currently more important in Europe, but as the Muslim and religious Christian minorities grow, they will become as important for conservative politicians as the religious Hispanics of America whom the Republicans have so assiduously courted. At some point, it will make more electoral sense for European conservatives to appeal to a trans-ethnic coalition of moral conservatives than it will to stress anti-immigrant themes and ethno-nationalism. The liberal-left will find it extremely difficult to craft a defense of secularism given its investment in cultural relativism, the exhaustion of its secular religions, and its laissez-faire attitude to demographic change.

Standing back from the fray, we can think of demography as the achilles heel of liberalism. Rather than economic contradictions between capital and labour (Marx), or cultural contradictions between work and leisure (Bell), this book highlights the demographic contradictions between individualism and reproduction inherent in the liberal-capitalist model.

Trends in Global Religiosity

Global trends indicate a rise in conservative religiosity. Conservative Judaism, Protestantism and Islam are the leading outriders of this movement, but radical Hinduism 
and charismatic Catholicism are also resurgent. Demography is the main engine of growth for Islam, and is also important for Christianity. Socio-political forces (i.e. switching, secularisation) are most important for Christianity, as well as for atheism/nonreligiosity, which has suffered a net loss of converts in recent decades due to the collapse of communism after 1989. (Johnson and Barrett 2004; Toft and Shah 2006) These developments inform two major debates. The first concerns secularization (or its reversal), in both its 'public' (i.e. separation of religion from the state) and 'private' (decline of personal piety) dimensions. The second involves international security, whereby the rise of conservative religiosity enlarges the pool of suppliers of, and/or recruits to, terrorism; or affects the foreign policy behaviour of states. I term this second phenomenon demographic radicalization.

The Demography of Religious Conservatism

Differential ethnic population growth has been implicated in a number of ethnic conflicts, from Lebanon and Northern Ireland to Israel/Palestine, Bosnia and Cote D'Ivoire. (Slack and Doyon 2001; Toft 2002) This raises the possibility that the same may hold for differential religious population growth between fundamentalists and the moderate/secular population. We are used to thinking about the high fertility of particular religious traditions, such as Catholicism or Islam. However, demographers have increasingly found that as societies modernise, differences between religions become less important than differences within religions unless religion serves as a marker which is mobilised by self-conscious ethnic identities. (Westoff and Jones 1979) This is extremely 
relevant today, because an important postulate of second demographic transition theory is that values are increasingly linked to fertility behaviour as societies modernise. Whereas the first phase of transition is affected by material changes like urbanisation (which renders children more costly and less beneficial), falling infant mortality and the availability of contraception, latter-day declines are more consciously 'chosen' on the basis of values and attitudes. Conservative religious values are associated with higher fertility while liberal or secular values predict lower birthrates. (Surkyn and Lesthaeghe 2004; van de Kaa 1987)

This dynamic increases its importance in the modern period because previous to this both religious conservatives and others had high fertility, cancelled out by high mortality. Only as mortality falls do differences in fertility become more important - and here we find that conservative religious groups have not responded to falling infant mortality as others have: i.e., by dropping their fertility to the replacement level, or below. (Skirbekk, forthcoming) When everyone had ten children and eight died before they reached adulthood, beliefs didn't matter. Today they do. Religion is particularly important in ethnically homogeneous societies or in contexts where ethnic cleavages fade, because religiosity can more easily come to the fore as a political cleavage.

Israel and the Jewish Diaspora

Nowhere is the religiosity-fertility nexus as stark as in Israel and the Jewish diaspora. On 8 Feburary, 2007, Israeli economist David Ben David wrote in Ha'aretz: 
It is difficult to overstate the pace at which Israeli society is changing. In 1960, 15 percent of primary-school pupils studied in either the ultra-Orthodox or the Arabsector school systems (these are today's adults). In 1980, this rate reached 27 percent, and last year it was 46 percent. (Ben David 2007)

The trends sketched by Ben David have radical implications in a society founded by secular Zionists ${ }^{1}$ (see Figure 1). Both Israeli Arabs and the ultra-Orthodox were opponents of the Zionist project prior to 1948 and are economically less successful than non-Orthodox Jews, yet both groups will be increasingly important players in the Israeli polity due to their growing demographic weight. ${ }^{2}$ Even with their small numbers, the ultra-Orthodox already have held the balance of power in the Knesset and are courted by the major parties.

\section{Figure 1}

\section{Percentage of pupils in Arab and ultra-Orthodox primary schools, 1960-2006}

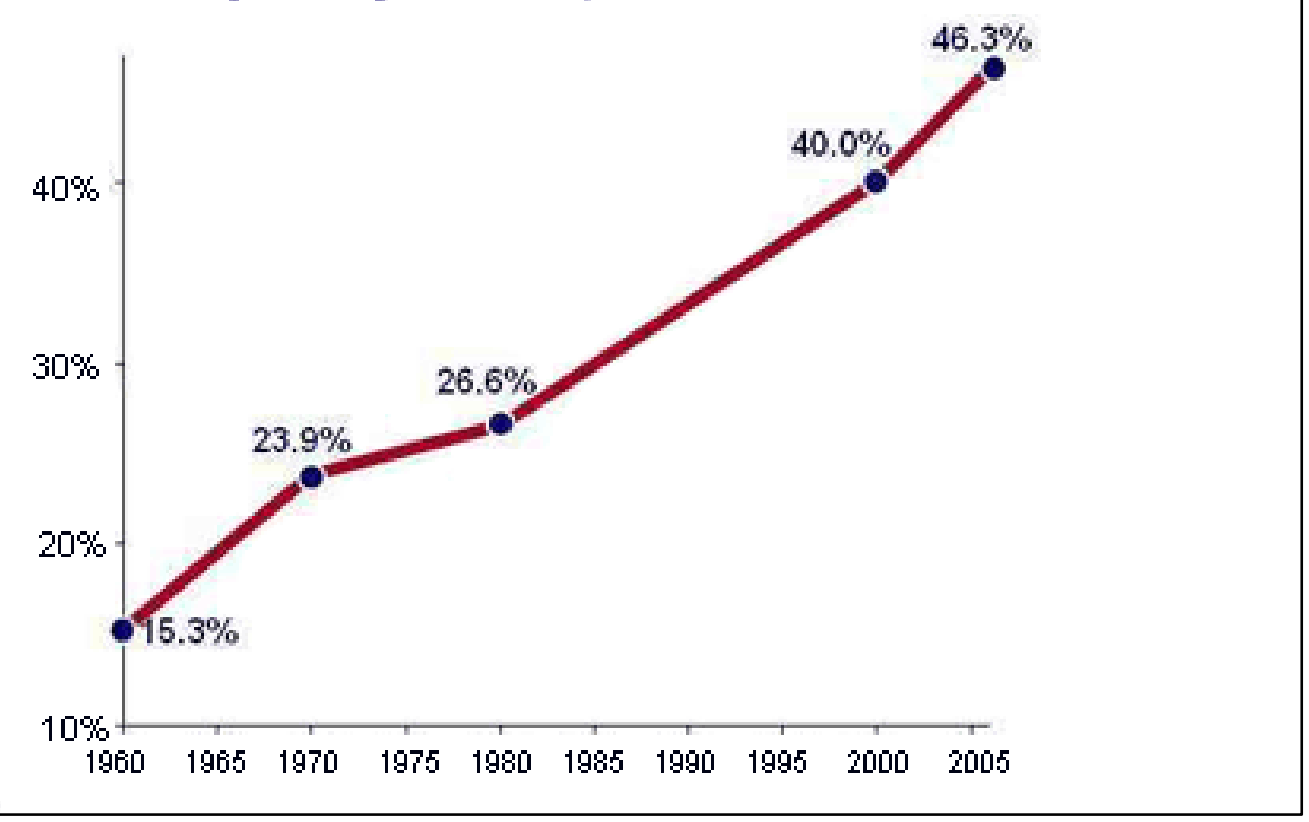


Source: 'The Moment of Truth', Ha'aretz, 8 February 2007

The Israeli case simply illustrates, in extremis, a dynamic whose effect moves from the demographic to the social and then to the political sphere. Among ultraOrthodox Jews (Haredim), for instance, fertility rates rose from an already staggering 6.49 children per woman in 1980-82 to 7.61 during 1990-96; among other Israeli Jews, fertility declined from 2.61 to 2.27 (Fargues 2000). In the absence of a large-scale 'switching' of allegiance by the children of the ultra-Orthodox, Haredi Jews will double their population, increasing their share of Israel's Jewish population to a whopping 17 per cent by 2020. (Wise 2007) Once a fringe minority, Haredim will emerge as a major political bloc. The idea that Israel is becoming more secular is simply untenable in the face of these demographic trends. What, we might ask, does this mean for the future of Israeli policy with regard to land for peace, the settlements and the status of the holy places of Jerusalem?

Historically, the Haredim opposed the Zionist movement because the return of the Jews to the promised land was supposed to occur through divine intervention. Human intercession - in the form of Zionism - ran counter to God's Plan. Moreover, the split between Orthodox Jewry and Herzl's Labour Zionism was severe. Though there were religious supporters of Zionism, most Zionists openly scorned Orthodox Judaism as an antiquated relic responsible for the subordinate plight of the Jews. However, there has been somewhat of a rapprochement in recent decades. To begin with, Haredi parties like Agudat Yisrael and Shas have participated in Israeli politics, sometimes holding the balance of power in the Knesset between Labor and Likud. They have proven pragmatic 
in their foreign policy preferences, and often support Israeli security measures and the aspirations of Zionist settlers in the West Bank and Gaza.

There is also a small but important Haredi Zionist movement. When separated, Ultra-Orthodox Judaism and secular Zionism are powerful forces. Fused, they enervate each other to produce a potent cocktail. The religious and nationalist strands of Judaism were strongly entwined in the persona of Rabbi Abraham Isaac Kook. Born in Russian Courland, in what is now Estonia, in 1865, Kook sought to reconcile the two solitudes of Orthodox Judaism and secular Zionism. He foresaw that Zionism, in leading to an ingathering of the Jews after 2000 years of exile, was a prelude for the spiritual messianic redemption of World Jewry. The sacrifices of the settlers would hasten this redemption. In 1904, Kook moved to Palestine, where he became the leader of the religious Zionist movement and helped build bridges between secular and religious Jews as Chief Rabbi of Palestine. Later, his son Zvi Yehuda influenced the Hardal political movement of religious Zionism. The religious Zionist movement largely consists of a more modernOrthodox wing (Mizrachi) branch, but also encompasses an ultra-Orthodox wing (Hardal) which is Haredi in philosophy. Hardal is hawkish on foreign policy, with many of its adherents living in the Occupied Territories and supporting the idea of a Greater Israel.

The Settler movement, notably the Gush Emunim (Community of the Faithful), draws strongly on the religious Zionism of the elder and younger Kooks. One of the tributaries of religious Zionism is the Gush Emunim Underground, a terrorist offshoot of the Gush Emunim. During 1979-84, its members mounted a series of attacks in retaliation for Arab terrorist attacks. Gush Emunim Underground members were implicated in a 
number of terrorist incidents, including a daytime gun and grenade attack on the Islamic College of Hebron which killed 3 and injured 33. They also detonated two car bombs which maimed Nablus Mayor Bassam Shaka'a and Ramallah Mayor Karim Khalaf. These actions were endorsed by many within the wider Settler movement.

The case of Yigal Amir nicely exemplifies the potential connection between ultraOrthodoxy and religious violence. On November 4, 1995, Amir, together with his brother Hasai and another accomplice, Dror Adani, assassinated Yitzhak Rabin, the popular Israeli Labour prime minister. Winner of the 1994 Nobel Peace Prize for his role in signing the Oslo Accords which recognised Palestinian control of parts of the West Bank and Gaza, Rabin was widely reviled by religious Zionists. Amir was no exception. Born into a Haredi family of Yemeni descent, he attended a Haredi elementary school and yeshiva before entering the Israeli defense forces as a Hesder student. Though most yeshiva students are exempted from military service, an important number choose to participate in Hesder programmes which combine Talmudic study with military service. This provides an important outlet for Haredim with religious Zionist orientations. As one exponent explains it, Hesder helps reconcile the potentially conflicting spiritual and patriotic duties of religious Zionists:

The defense of Israel is an ethical and halakhic imperative - be it because, as we believe, the birth of the state was a momentous historical event and its preservation of great spiritual significance or because, even failing that, the physical survival of its three million plus Jewish inhabitants is at stake. 
The author also added an amusing anecdote intended to awaken more otherworldly Haredim to the importance of military imperatives:

The story is reliably told of a leading rosh yeshiva (Haredi yeshiva student) who...attended a wedding near the Israeli-Arab border in Jerusalem. At one point, gunfire was suddenly heard and he scurried under a table, exclaiming passionately, "Ribbono shel olam, I want to live! There is much torah which I yet wish to learn and create!"...I cite the story...in order to point out that, at a certain distance, one can lose sight of the simple truth that a Jewish soul can only exist within a Jewish body. (Lichtenstein 1981)

The connection between Amir's religious conservatism and his terrorist acts makes sense. But the fact that Rabin's peace-seeking coalition included Shas, a Haredi party, should caution us against jumping to any hasty conclusions. Conservative religion enlarges the pool of religious terrorists, but can also work for peace - the two are not in contradiction. An important source of settlers and funding for religious zionism is the diaspora. Therefore it is critical to go beyond Israel to grasp whether demographic radicalization has affected the other half of world Jewry. The answer is provided by the Tribune, the principal organ of Britain's Haredi community, which recently thundered: 'We will be the majority by 2050'. The paper's claims are based on research by historian Yaacov Wise of the University of Manchester. Wise found that Haredim now comprise 17 percent of the UK's Jewish population but account for three quarters of all British Jewish births. The high Haredi fertility rate had managed to reverse the long-term decline in the 
UK Jewish population. In Manchester, a third of Jews are already Haredi, up from a quarter just ten years ago. (Wise 2007) Where once the ultra-Orthodox sought to secede from mainstream diaspora Jewish organizations, now their population surge and demographically-inspired confidence will put them in a position to take them over during the course of the twenty-first century.

Once again, demographic radicalization springs from the connection between religiosity and fertility. Consider the relationship between religiosity and fertility in a pooled sample of European Jews collected from European Values Surveys (EVS) of 1981-97 (see Figure 2). Among Jewish women who have completed their fertility (those over-45), the average number of children ever born to women who describe themselves as 'religious' is just under 3. Among those who describe themselves as 'not religious' this figure drops to 1.8, while atheist women bear less than 1.5. This pattern seems even stronger among a rising generation of Jewish women who have yet to complete their fertility (aged 18-44), with religious women nearly at the replacement level while nonreligious have borne just 1.2 and atheist women 0.7 children, on average. 


\section{Figure 2}

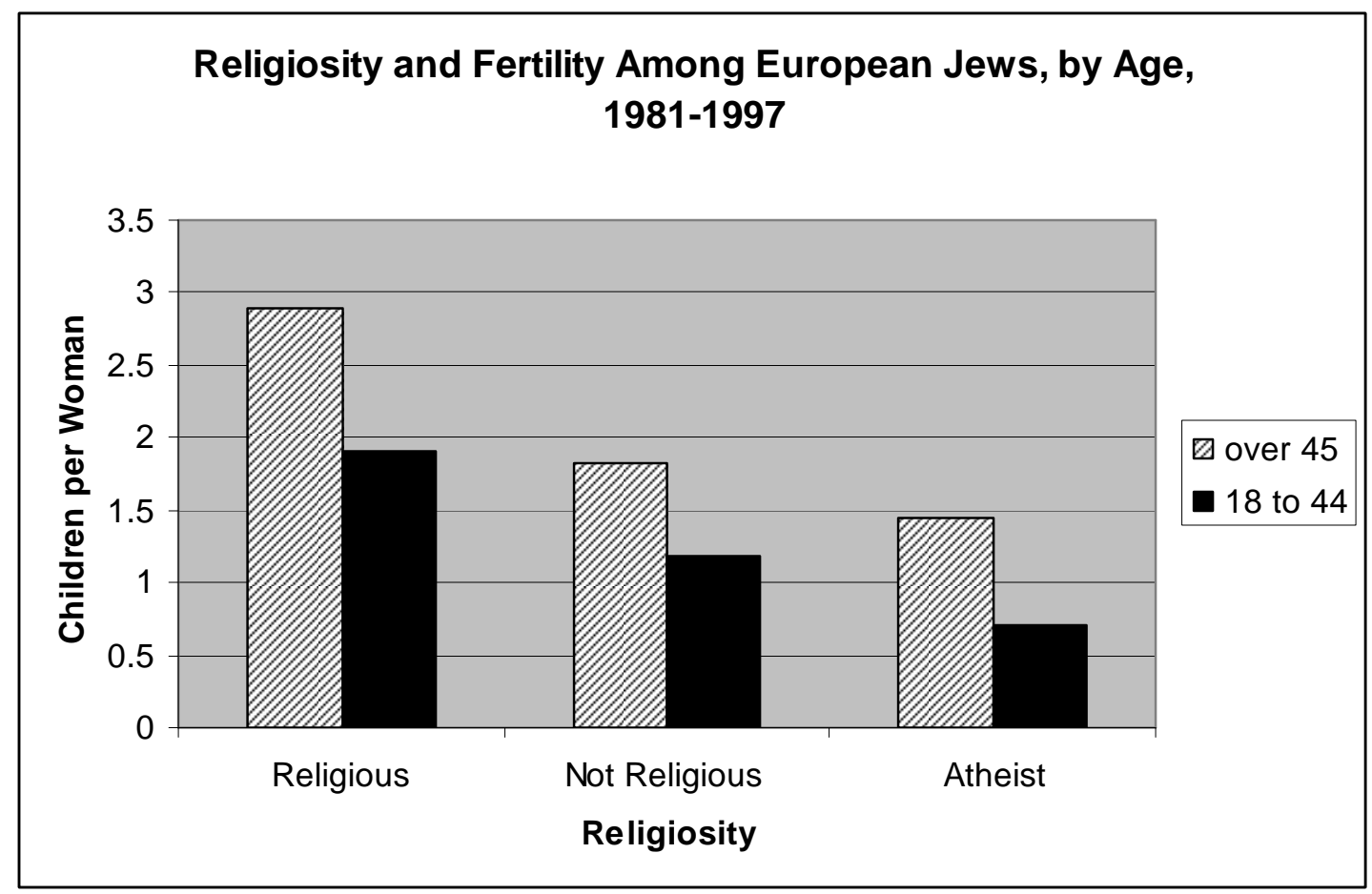

Source: European Values Surveys 1981, 1990, 1995-97 combined sample. Total of 852 Jewish respondents under 45 , and 419 over 45 .

The divergent trajectories of ultra-Orthodox and other Jews is accentuated by the vanguard fertility behaviour of secular or moderate Jews. In Europe, we have seen that nonreligious Jews over age 45 already had below replacement fertility in the period 198197. Though we do not have specific information on the ultra-Orthodox, we can get at this by looking at a microcosm of European Jewry - Britain, where census data on religion enables us to look more closely at relevant trends. The story of British Jews is really that of two communities: a demographically vibrant but economically deprived segment, the ultra-Orthodox, and an aging, economically successful majority of secular/moderate Jews. The latter are also more susceptible to assimilation and intermarriage, accentuating 
their decline within British Jewry. Contrast the age pyramids of the Jewish communities of Salford, near Manchester, with that of Leeds. Salford's Jews are primarily, though not exclusively, ultra-Orthodox, while Leeds has very few Haredim. (See figures 2a and 2b)

\section{Figure 2a}

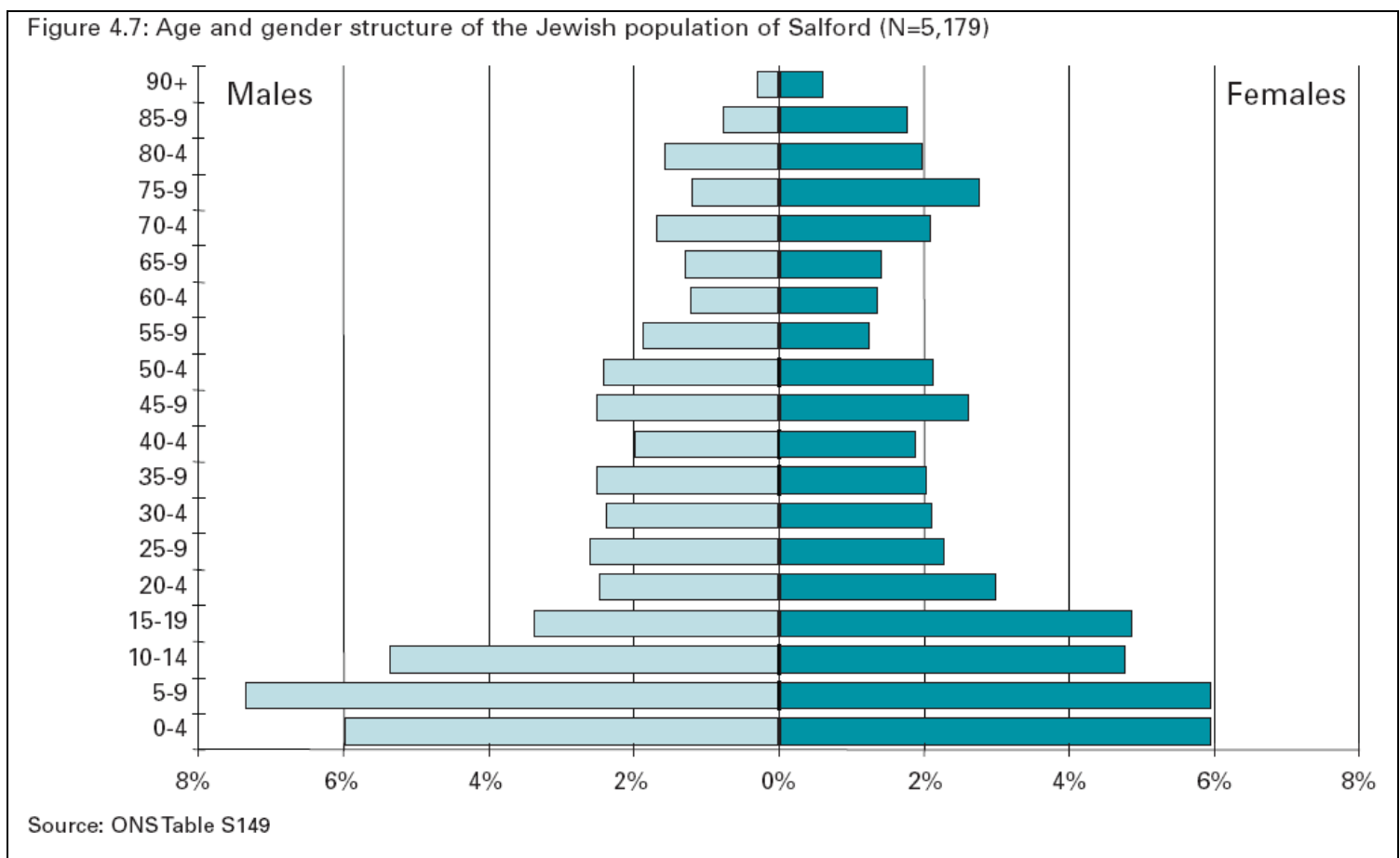

Source: Graham, Schmool et al. 2007: 44 


\section{Figure 2b}

Figure 4.6: Age and gender structure of the Jewish population of Leeds $(N=8,273)$

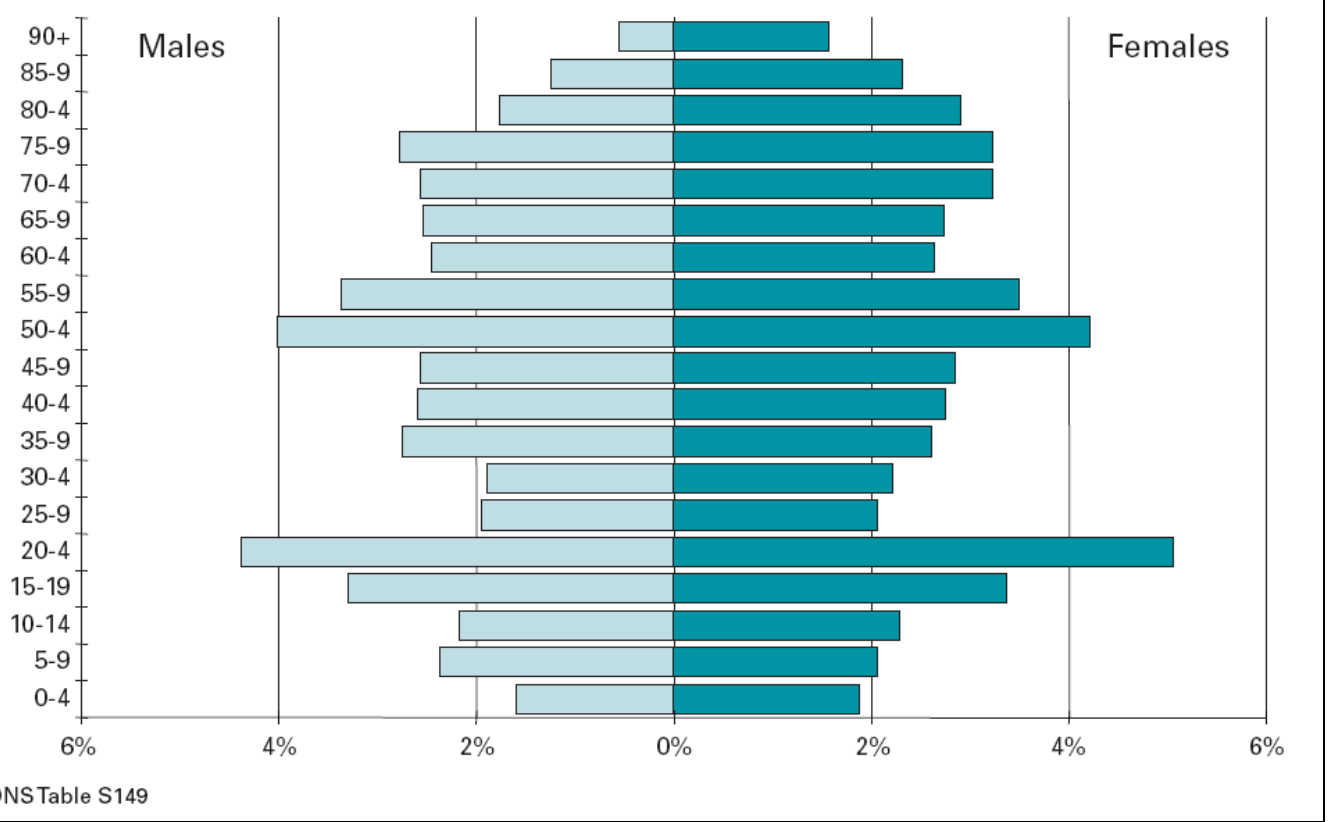

Source: Graham, Shmool et al. 2007: 43

Taking the principal centres of ultra-Orthodoxy in Britain, Salford and Hackney (in East London), we find just 10 percent of the Jewish population over 65 and approximately 35 percent under 14. Countrywide, nearly a quarter of British Jews are over 65 and only 16 percent are under 14. In Leeds, the proportion under 14 is just 12 percent and well over a quarter are over 65. (Graham, Shmool et al.: 40-44)

In the United States, the General Social Surveys of 2000-2006 show that Jews have the lowest fertility of 11 ethnoreligious groups (1.43). As in Europe, this low fertility is combining with low rates of conversion to reduce the Jewish proportion of the American population. Among those born after 1945, there are now more Mormons than Jews, and Muslims will overtake Jews by 2025, perhaps heralding a historic sea change in American foreign policy, with its traditional support for the state of Israel. 
(Mearsheimer and Walt 2006) Within this largely secular/moderate Jewish community, the Haredi minority are estimated to have increased their share of the American Jewish total from 7.2 to 9.4 percent over the short period 2000-2006 alone, calculates Professor Joshua Comenetz of the University of Florida. (Hoover 2006) Most American ultraOrthodox Jews live in greater New York, either in traditional tightly-knit Hasidic settlements in Brooklyn, or in new, outlying rural colonies. The small Hasidic settlement of Kiryas Joel, in Orange County, New York, for example, almost tripled in population, from 6,000 to 18,000, between 1990 and 2006. (Kraushaar 2007) Ultra-orthodox Jews are politically significant because they are more likely than other Jews to vote Republican. This is mainly because of Republican support for faith-based social policy and traditionalist moral values. Yet, for some ultra-Orthodox and modern-Orthodox Jews, the affinity between Christian Republican and Jewish religious Zionism also matters. Republican support for more muscular pro-Israeli foreign policies may also prove attractive to some.

Religious beliefs shape fertility, but can also shape other aspects of demographic behaviour. Intermarriage, for instance, is a burning demographic issue among American Jews, since roughly half of young Jews now marry those of other faiths. The identities of their children are unclear, but the phenomenon has sparked a debate in the Jewish community over how best to keep these 'part-Jewish' Jews within the fold. Mainstream Jews have suggested a relaxation of traditional Jewish matrilineal descent rules to enable those with Jewish fathers but non-Jewish mothers (such as myself!) to remain Jewish. However, the ultra-Orthodox have resisted these initiatives in America because they purportedly stray from orthodoxy - much as they have in Israel when discussing "who can 
be a Jew' and thus emigrate to Israel under the provisions of the Law of Return. Haredim have tended to withdraw from the wider society, but have actively participated in politics in both Israel and the diaspora. As the number of ultra-Orthodox voters swells, the Haredim will acquire influence in the Knesset and in diaspora Jewish organisations. This will enable the Haredim to impose an orthodox definition of Jewishness on mainstream Jewish institutions during the course of the twenty-first century. In general, an increasingly Haredi Jewish population may decrease the strategic flexibility of Israeli society, polarising it between otherworldly pacifism and religious Zionist zealotry.

On the one hand, more quietist Haredi voters may increase the power of postZionism and the forces of peace. Yet one should not overstate this outcome. Most Haredim support the state of Israel, and understand that they would do far less well in a Palestinian state - this is certainly reflected in the pragmatism of their elected representatives. More important therefore is the significant minority of the ultraOrthodox (as well as the modern Orthodox) who combine orthodoxy with Zionism. Religious zionists have been responsible for a numerous Jewish terrorist actions in recent years. A demographically-fuelled religious Zionism will generate increased recourse to sacred rather than strategic logics. This may box in Israeli policymakers, precluding solutions to some of the thorniest problems in the peace process, such as territorial boundaries, and the status of Jerusalem and its Holy Places. Where these problems call for splitting the difference, a religiously doctrinaire approach seeks absolutism. This cannot bode well for the security of this region in the decades to come.

That said, religious Zionists are a distinct minority within Haredi society. The bulk of the Haredi population will probably continue to support pragmatism in foreign 
policy while insisting on puritanical domestic cultural policies as well as continued state support and military exemption for yeshiva students. This may make Israel a more socially conservative society, but will contain the risk of Israeli state intransigence. The wildcard, of course, will be increased religious Zionist terrorism - whether directed against Israeli Arabs or against liberal Israeli targets.

\section{United States}

The United States is no exception to the trend of demographic radicalization. This has accentuated as ethnic and confessional differences faded in the late twentieth century, bringing religion to the fore as a political issue. As American society became more ethnically porous in the 1970s, alliances were forged across Protestant, Catholic and Jewish lines by moral traditionalists. This alliance was subsequently drawn into politics in the 1980s as the newly-coined 'Moral Majority' by three conservative activists, Richard Viguerie, Paul Weyrich and Howard Phillips. Fittingly, the first two were Catholics, the third a Jew, and their chosen figurehead was the late Jerry Falwell, an evangelical Protestant. (Bruce 1998: 148-9) The new ferment prompted Robert Wuthnow to remark that 'the major divisions in American religion now revolve around an axis of liberalism and conservatism rather than the denominational landmarks of the past' (Wuthnow 1989: 178). The term 'culture wars' emerged on the back of these changes, reflecting not only socio-religious changes, but the opening up of a new political axis based on religious and moral traditionalism, which crosses ethnic and denominational lines. (Hunter 1991; Fiorina, Abrams et al. 2005) 
In the United States, white Catholics no longer have higher fertility than white Protestants, but women with conservative beliefs on abortion (whether Catholic, Protestant or Jewish) bear nearly two-thirds of a child more than those with pro-choice views. (Kaufmann, Goujon et al. forthcoming) Conservative denominations also have higher fertility than more liberal ones, not to mention seculars. (Skirbekk, Goujon et al. forthcoming) American research also suggests a significant link between various measures of religiosity (congregational participation, denominationational conservatism, attendance) and fertility. Participation in congregational groups is especially important. (Hackett 2008) During much of the twentieth century, women in conservative Protestant denominations bore almost a child more than their counterparts in more liberal Protestant denominations. This was the main reason why conservative Protestants increased their share of the white Protestant population from roughly a third among those born in 1900 to nearly two-thirds of those born in 1975. (Hout, Greeley et al. 2001) Individual-level relationships are reproduced through compositional effects at the state level, hence higher white fertility in states with large Mormon or evangelical Protestant populations. Indeed, there was a correlation of .78 between a state's white fertility rate and its 2004 vote for George W. Bush, an effect strongly mediated by religious traditionalism. (Hout, Greeley and Wilde 2001; (Lesthaeghe and Neidert 2006). After all, 78 percent of white evangelicals voted for Bush in 2004 (including a majority of Hispanic Protestants), as did solid majorities of theologically traditionalist Catholics and mainline Protestants. Seculars and theologically modernist Christians of all denominations, by contrast, overwhelmingly backed John Kerry. The 2008 election shows only a modest change in this pattern. (Guth, Kellstedt et al. 2005) (Guth 2008) 
The political theology of conservative Christianity does not incline its members toward violence in the United States today, and global charismatic and Pentecostal Christianity - with a few notable exceptions such as the Lord's Resistance Army of Uganda - shares the same pacific orientation. (Berger 2008) However, shifts in context and interpretation could change this, as there are historical resources in the bible which could be used to motivate armed conflict. It is also worth remembering that there have been domestic terrorist incidents (bombing of abortion clinics, Oklahoma City bombing) that have been inspired, at least in part, by a fundamentalist reading of the bible. The National Abortion Federation has tracked anti-abortion terrorism in the United States for several decades. It documents 7 murders, 17 attempted murders, 41 bombings, 173 arson attacks, 100 butyric acid attacks, 157 incidents of assault and battery, 4 kidnappings, and 385 death threats between 1977 and 2006. (NAF 2008)

Naturally the more significant impact of Christian fundamentalism will be felt in the cultural climate and in domestic public policy. The Christian Right's policy agenda encompasses opposition to abortion, homosexual rights, pornography, evolution and sex education; and the promotion of family values, school prayer, independent schooling and government funding for faith-based charities. Today, its political influence at local, state and federal levels is in abeyance, symbolised by the defeat of George Bush in the 2008 presidential election. Jerry Falwell's Moral Majority crested in the 80s and the Christian Coalition surged in the 90s, but the Religious Right's social movement organisations overplayed their hand, inviting countermobilisation by fiscal conservatives and liberals. The Christian Right is currently licking its wounds - even failing to implement its antiabortion and school prayer agenda in strongholds like South Carolina and Texas. (Green, 
Rozell et al. 2006) Yet the Religious Right has changed the terms of political discourse and elevated the importance of religious symbolism in public life. Furthermore, the demography of the nation suggests that God may ultimately be on the side of the Religious Right.

Europe

What of European Christianity? The conventional wisdom holds it to be in free fall, especially in Western Europe. (Bruce 2002) This is undoubtedly correct for Catholic Europe, while Protestant Europe already has low levels of religious practice. Yet closer scrutiny reveals an increasingly lively and demographically growing Christian remnant. Several studies have examined the connection between religiosity - whether defined as attendance, belief or affiliation - and fertility in Europe. Most find a statistically significant effect even when controlling for age, education, income, marital status and other factors. (Adsera 2004: 23; Frejka and Westoff 2006; Berghammer, Philipov et al. 2006) Traditionally, education was seen as the key determinant of a woman's fertility rates. Yet in many of these European studies, a woman's religiosity is as or more important than her level of education in determining the number of children she will bear over a lifetime. In Spain, women who remain practicing Catholics are now considerably more fertile than their non-practicing sisters, which wasn't the case as recently as 1985 . This is most likely because only those truly committed to religion remain attenders while nominal Catholics have dropped away as Francoist conformity collapsed after 1975. 
Since the more religious are more fertile, the departure of nominal, uncommitted attenders helps unmask the connection between religiosity and fertility.

In France we find the same dynamic. Against a backdrop of European fertility decline, fertility rates actually rose substantially among practicing, native-French Catholic women born after 1950. Meanwhile, the fertility of non-practicing and nominal Catholics remained flat. Among French women born in 1960, there is a half-child difference in fertility between practicing Catholics and nonpracticing Catholics. The authors estimate that religious decline in France in the twentieth century accounts for 1518 percent of the country's inter-cohort fertility decline. (Regnier-Loilier and Prioux 2008))

Moving to the wider spectrum of European Christianity, we find that fertility is indeed much higher among European women who are religious. The European Social Survey (ESS) of 2004 asks 'how religious are you', and provides a scale from 0 to 9 . In a sample of ten west European countries (chosen because they were the only ones sampled in all three waves of the European Values Survey), the number of women who were very religious (6-9) was similar to those with low religiosity (0-4). However, the fertility of the two groups differed greatly. Women who said they were very religious (6-9), bore, on average, 1.95 children, as against 1.42 for those in the least religious (0-4) deciles. Among those 45 and over, the difference was 14 percent (TFR pf 2.39 v. 2.07), but in the under-35 group, the gap was a whopping 159 percent (TFR of 1.42 v. .53). The stronger effect in younger age cohorts suggests an emerging, 'second demographic transition' dynamic. Data from the 2000 European Values Survey in the same countries reaffirms the pattern, albeit more modestly: 'religious' women have a 24 percent fertility advantage 
among the under-35s as against 10 percent for the over-44s. Part of this is due to a tempo effect of religious women bearing children earlier, and only time will tell how much of the gap will be closed by less religious women in the years ahead.

Today, most of those who remain religious in Europe wear their beliefs lightly, but conservative Christianity is hardly a spent force. Data on conservative Christians is difficult to come by since many new churches keep few official records. Reports from the World Christian Database, which meticulously tracks reports from church bodies, indicates that 4.1 percent of Europeans (including Russians) were evangelical Christians in 2005. This figure rises to 4.9 percent in northern, western and southern Europe. Most religious conservatives are charismatics, working within mainstream denominations like Catholicism or Lutheranism to 'renew' the faith along more conservative lines. There is also an important minority of Pentecostals, who account for .5\% of Europe's population. Together, charismatics and Pentecostals account for close to $5 \%$ of Europe's population. The proportion of conservative Christians has been rising, however: some estimate that the trajectory of conservative Christian growth has outpaced that of Islam in Europe. (Jenkins 2007: 75)

In many European countries, the proportion of conservative Christians is close to the number who are recorded as attending church weekly. This would suggest an increasingly devout Christian remnant is emerging in western Europe which is more resistant to secularization. This shows up in France, Britain and Scandinavia (less Finland), the most secular countries where we have 1981, 1990 and 2000 EVS and 2004 ESS data on religiosity. EVS and ESS data indicate that generations born after 1945 are as likely to attend as older cohorts. Though just 5 percent of people attend in these 
societies, nearly half describe themselves as religious, and their presence indicates a flattening out of the long secular trends of the twentieth century. (Kaufmann (Kaufmann 2008) Unfortunately, we have no direct source of information on the fertility of Pentecostals and charismatics in Europe. A worldwide study suggests that Pentecostals have higher fertility than others in the United States, but not in Latin America, Africa or Asia. (Pew Forum on Religion and Public Life 2006: 40) This could signify the lack of a religiosity-fertility link, but may also result from a greater outworking of second demographic transition dynamics in the more developed context of the USA. Certainly there are significant data limitations in both the WCD and Pew studies, thus more research is needed in this area in order to substantiate whether Pentecostals have higher fertility in the second demographic transition contexts of northern, western and southern Europe. ${ }^{3}$

Finally, a major source of conservative religious growth in Europe is immigration. The main flows involve Muslims, from the Middle East (especially North Africa) and South Asia, and Christians, largely hailing from Africa, parts of Asia, Latin America and the West Indies. West Europe's population of non-European extraction is projected to triple between now and 2050, from roughly $4-5$ percent to $12-15$ percent, reaching as high as 25 percent in societies like Holland, France and Britain. (Coleman 2006) Few of these newcomers will be secular. Perhaps 60 percent will be Muslim, who, as we shall see, show few signs of secularisation. (Jackson, Howe et al. 2008: 123) But religious immigration goes beyond Islam to encompass Christianity, which is reaping a demographic dividend nearly as impressive. In England, more Muslims attend mosque on a weekly basis than Anglicans attend church, but Christianity is hardly stagnant: 58 
percent of London's practicing Christians are nonwhite. (Islamonline 2005) The Global South is today's engine of world Christianity, symbolized by the appointment of Ugandan-born John Sentamu as Anglican Archbishop of York in 2005. At the epicenter of global southern Christianity stands Pentecostalism, its most exuberant, fast-growing form. A quarter of the world's Christians are now believed to be Pentecostals, with most of the past half-century's growth taking place through conversion among Catholics in Latin America, Animists in Africa and Buddhists or secularists in East Asia. (Jenkins 2007; (Martin 2001; World Christian Database 2008)

The urban church is essentially an immigrant church in Britain, but this is also becoming true elsewhere in Europe. In France, evangelical Protestants have swelled from 50 to 400 thousand inside 50 years, chiefly because of immigration. Even Catholicism and mainline Protestantism benefit. In Denmark, immigrants fill the once ailing Catholic churches and have prompted a demand for more. (Jenkins 2007: 93-6) In Ireland, Polish and Lithuanian Catholics are replacing increasingly nonreligious young Irish in the churches. In Europe as a whole (including Russia), pentecostals and charismatics have exploded in numbers, expanding in step with Islam. Currently there are more evangelical Christians than Muslims in Europe. (Jenkins 2007: 75) In Eastern Europe, as outside the western world, Pentecostalism is a sociological and not a demographic phenomenon. In Western Europe, by contrast, demography is central to evangelicalism's growth, especially in urban areas. Alas, immigration brings two foreign imports, Islam and Christianity, to secular Europe.

The combined impact of native religious fertility and religious immigration will be to re-sacralise Europe. Its seemingly inevitable march toward secularism may one day 
come to be seen as an interregnum between its historic piety and multi-faith future. Projections which combine data on immigration, age structure, religious switching and fertility are instructive. We have performed these unprecedented analyses on several cases. Austria offers us a window into what the future holds. Its census question on religious affiliation permits us to perform cohort component projections, which show the secular population plateauing by 2050 , or as early as 2021 if secularism fails to attract lapsed Christians and new Muslim immigrants at the same rate as it has in the past. (Goujon, Skirbekk et al. 2006)

This task will arguably become far more difficult as the supply of nominal Christians dries up while more secularisation-resistant Muslims and committed rump Christians comprise an increasing share of the population. Data sources on European Islam - such as pooled Muslim samples of the EVS and ESS - shows similar levels of piety across all age groups rather than the decline from oldest to youngest which characterises Catholicism and other declining European faiths. (See figure 3) 


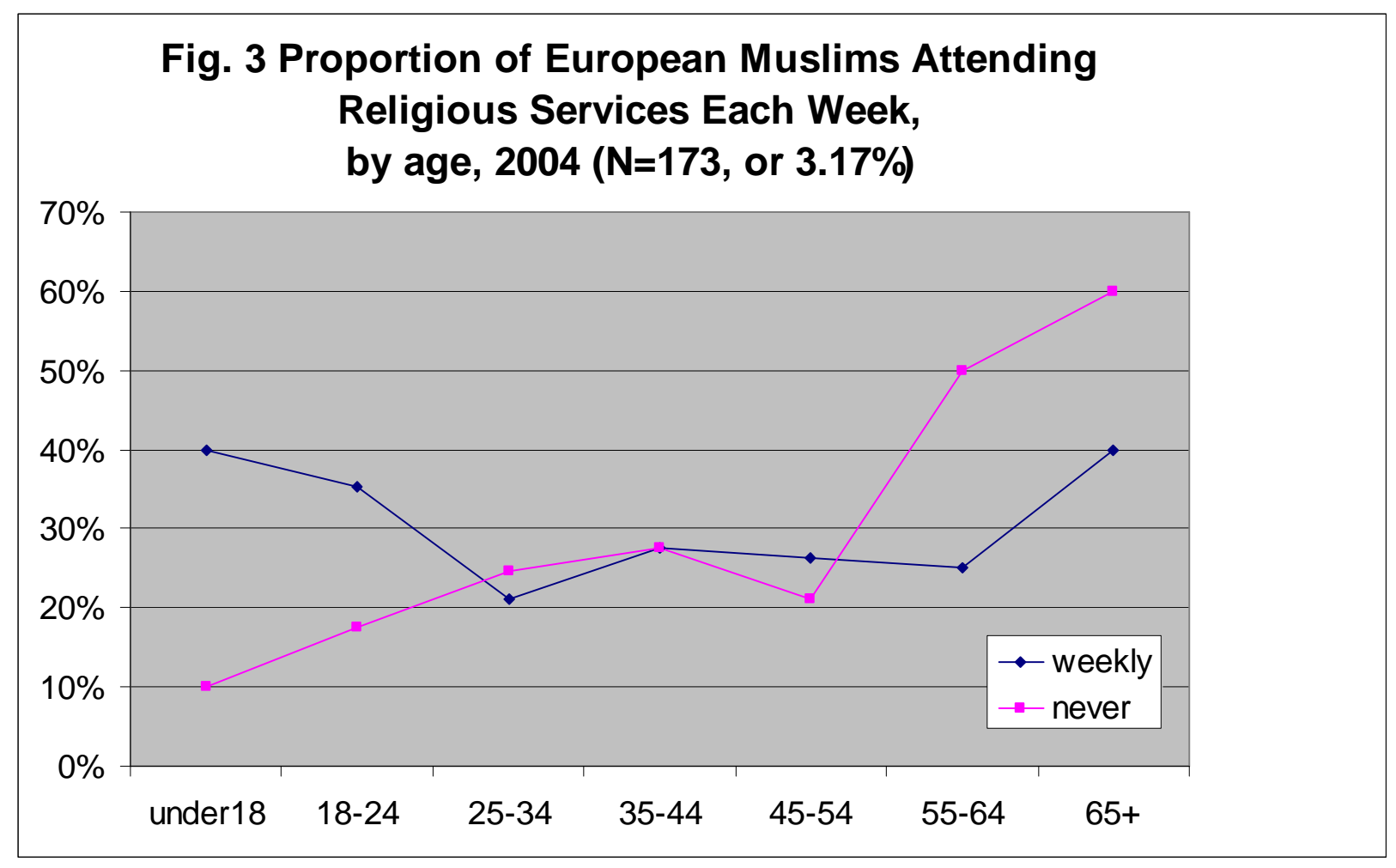

Source: ESS 2004

Minority studies which permit analysis of the second generation (for Holland and Britain only) appear to corroborate the picture of Islamic religious retention - with little or no slippage in attendance or belief between the immigrant and native-born generation. Several studies have discovered that immigrants to Europe tend to be more religious than the host population and - especially if Muslim - tend to retain their religiosity. (Van Tubergen 2006) Though some indicators point to religious decline toward the host society mean, other trends suggest that immigrants become more, rather than less, religious the longer they reside in the host society. (Van Tubergen 2007) Similar trends appear in UK ethnic minority surveys of 1994, 2001 and 2003 where sample size was not a problem and one could compare the immigrant generation with a second generation sample. (Home Office 2003; ONS 2005) The evidence clearly shows that while Afro- 
Caribbean Christian immigrants become more secular in the second generation, this is not true of Muslim ethnic groups, who have an almost perfect rate of religious retention. This accords with evidence from Dutch studies. (Van Tubergen 2006)

In other words, there is no evidence for Muslim secularisation. With Muslims set to comprise over half the non-European immigrants to western Europe in the coming half-century, this has important ramifications for the overall level of religiosity in the most secular countries of western Europe. In a period in which the native majorities of western Europe are experiencing the population decline predicted by thirty years of below-replacement fertility, immigration takes on greater importance as an agent of desecularisation. For example, figure 4 shows that the age structure of Muslim and Nonaffiliated (secular) Britons was similar in the 2001 census. Both are young populations, but the engine of growth is demographic in the Muslim case and sociological in the secularist case. In the future, as secularisation wanes, we would expect the nonaffiliated British population to begin to age, the Christian population to become slightly younger, and the Muslim population to remain broadly similar. Overall, religious-secular fertility differences and a slowing of Christian secularisation mean that immigration will lead to a more religious western Europe over the course of the twentyfirst century. 


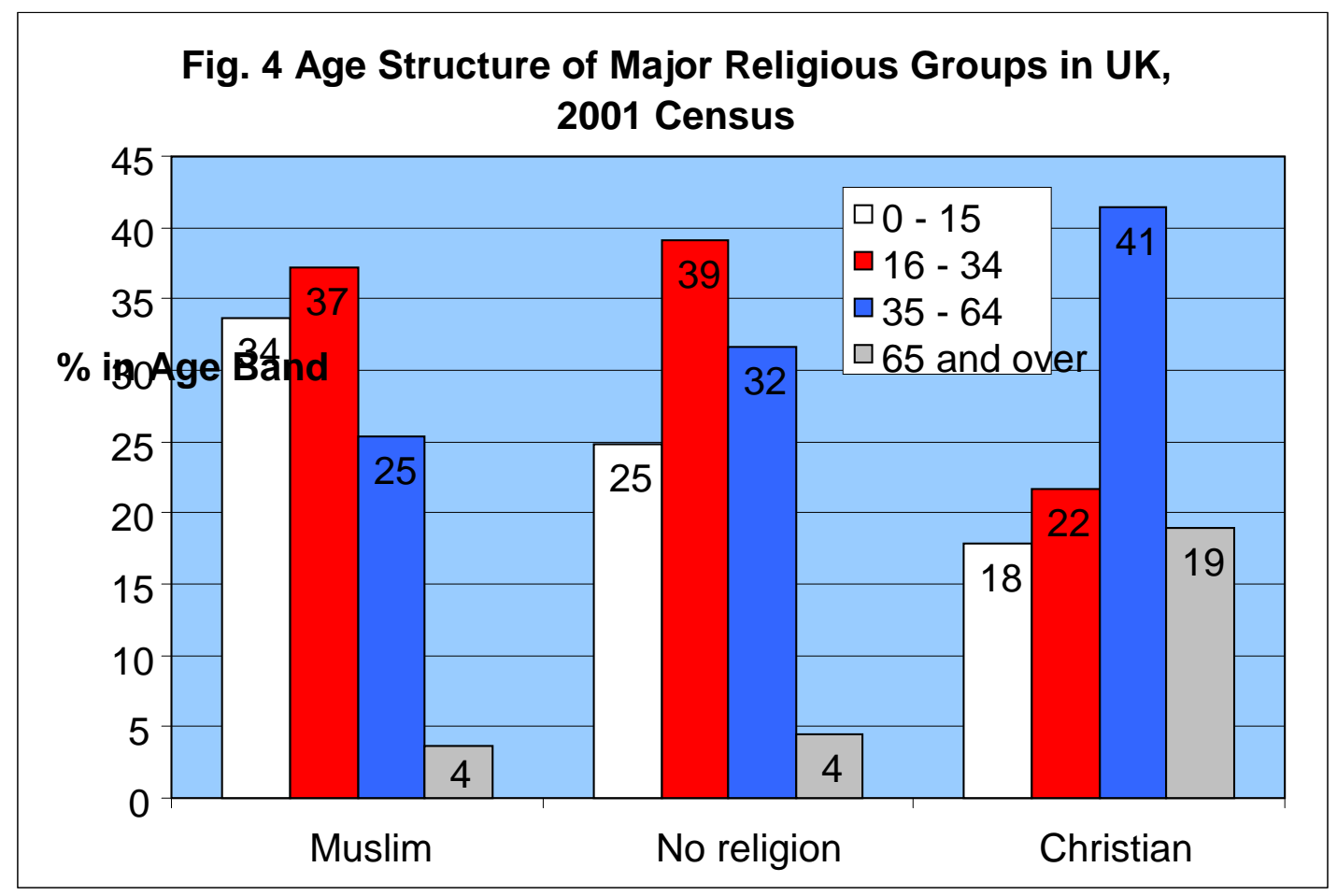

Source: Kaufmann 2007

Austria is one of the few European countries to collect religious data on their census. A recent attempt to project Austria's population to 2051 found that a combination of higher fertility and immigration will increase the proportion of Muslims (excluding apostates) in the country from 4.6 percent of the population in 2001 to between 14 and 26 percent by 2051. Certainly the secular/unaffiliated population increased from 4 percent in 1981 to 10 percent in 2001, and is projected to grow in the near future. However, the secular population in Austria has a total fertility rate (TFR) of just .86 children per couple, limiting its long-term growth potential. This means that in the event that secularisation ceases - to say nothing of religious revival - the secular population will peak and begin to decline as early as 2021. (Goujon et al. 2006: 24) Projections for Spain and Switzerland appear to be identical - in both cases, low secular fertility combines with 
religious immigration to act as a drag upon future secular growth, leading to reversal by 2050. Figure 5 shows what would happen to major religious populations between now and 2050 in Spain if the flow of apostates from religion to nonreligion ceases. Secularism appears unable to sustain itself without the (as yet unproven) large-scale religious apostasy of children of religious immigrants. Even in the unlikely circumstances that current levels of switching can be maintained, the secular population will peak by 2050 at just over 15 percent of the total. (Goujon and Skirbekk, forthcoming)

Figure 5. Spain: Projected Religious Composition to 2060 if Switching is Held

\section{Constant}

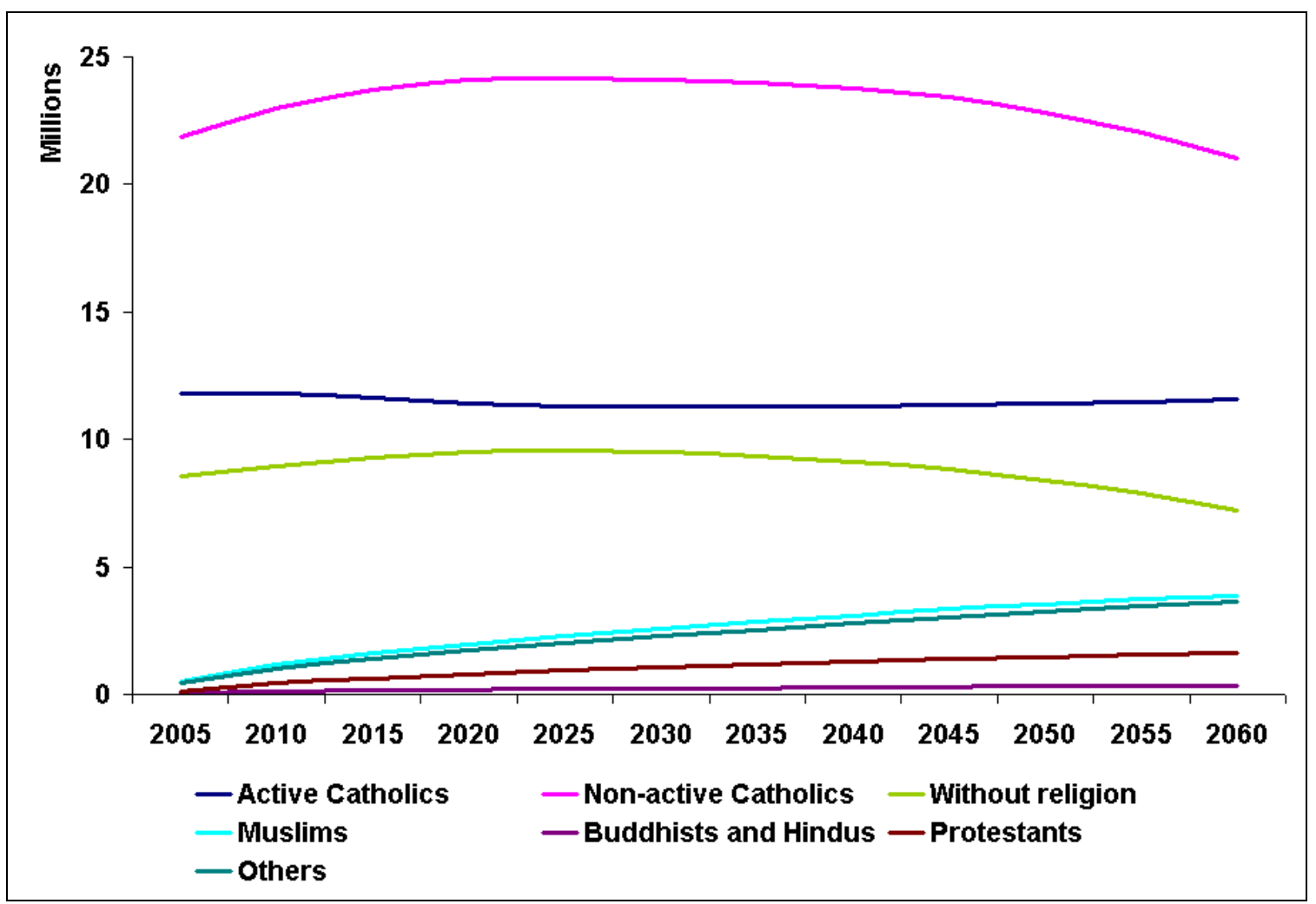

Source: Goujon and Skirbekk, forthcoming 
All of which suggests that secularisation may fail even if the secularisation thesis is correct. In other words, a combination of higher religious fertility and immigration will lead to a growth in the religious population (defined in terms of belief) of the most secular nations of Europe that exceeds the net loss of communicants through religious apostasy.

Islam

In most Muslim contexts, the demographic transition is still in its early or middle stages, so we would not expect to see as dramatic an effect. Still, we might ask: do Islamists have higher fertility than moderate Muslims, and what might we expect in terms of Islamist population growth and the demographic radicalization of Islam? In some cases, conservative Islam clearly delayed the onset of secular demographic processes, raising fertility. In Jack Goldstone's words, 'Some countries - mainly those with large Muslim populations - have been quite resistant to a reduction in birth rates; thus their population growth rates have remained high.' (Goldstone 2007) Pakistan is an interesting case, because it contrasts markedly with poorer Bangladesh next door. In Pakistan, religious authorities resisted birth control more than Bangladesh, whose principal brand of Islam has historically been less puritanical. The result is that Pakistan's population will hit 467 million by 2050, 188 million more than if it had adopted a Bangladeshi-style programme from the 1970s. (Cleland and Lush 1997) In Pakistan, 40 percent of the population is under 14. Total fertility rates in Somalia, Afghanistan, Yemen and the 
Palestinian Territories, for example, still exceed 5 children per woman. (Jenkins 2007: 8, 21; Fargues 2000)

Among the many Muslim societies that have embraced family planning, none is more striking than Iran. In the 1960s and 70s, the Shah pursued a westernization policy focused on getting women outside the home into education and work, and making contraception widely available. Fertility began to decline. Then came the Iranian Revolution in 1979 and the Iran-Iraq War in the 80s:

Appropriate Islamic public dress and appearance were codified and these rules strictly enforced; gender segregation was pervasive in public places; and domestic roles of women were glorified. Early marriage and motherhood were encouraged. Legal marriage ages were lowered to 9 and 14 for females and males, respectively. Family planning was labeled an imperialist plot to reduce the number of Muslims. Many family planning clinics were closed and clinic personnel transferred to other jobs. Fertility increased after the Revolution due to these changes and other pronatalist policies (some linked to the Iran-Iraq War). (Abbasi-Shavazi, Hossein-Chavoshi et al. 2007)

Iran did eventually change course, as policymakers and intellectuals lobbied clerics, who eventually sanctioned family planning as in keeping with the precepts of Islam, but the story is far from over.

Overall, the course of family planning in Muslim countries is one of qualified success. Yet state policy can change course if determined conservative factions gain 
power. Religious motivations may also dovetail with nationalist pronatalism. Outside of sub-Saharan Africa, Muslim fertility seems most resistant to decline in conservative Muslim societies like Yemen, Oman, Saudi Arabia and Pakistan. In Pakistan, the strong Deobandi fundamentalist movement has attacked the country's family planning policies as a western import linked to decadence, and an imperialistic attempt to control the Muslim population. They cite Koranic verses extolling the virtue of children and marriage and instructing families not to kill children during times of want. Sometimes fundamentalists dredge up the anticolonial Islamic Puritanism of Maulana Maudoudi, who, in a 1937 tract, savaged birth control as a western plot against Islam which would introduce western promiscuity and women's liberation into Pakistan (Karim 2005: 50-51) Elsewhere the threat is deadly serious. In Afghanistan and Pakistan's tribal areas, Taliban insurgents have taken to killing healthcare workers involved in family planning. Threats, kidnappings and assassinations have brought family planning to its knees in disputed areas. After murdering a female healthcare worker in Kandahar, Taliban insurgents wrote to her employer. "We took up arms against the Infidels in order to bring Islamic law to this land, 'they crowed in a letter bearing the seal of the Taliban military council. "But you people are supporting our enemies, the enemies of Islam and Muslims...Personnel were trained to distribute family planning pills. The aim of this project is to persuade the young girls to commit adultery.' (Blackwell 2008) In rural areas of Afghanistan and Pakistan, local religious leaders exercise great influence over people's views on contraception. In Taliban-dominated southern Afghanistan, people tend to accept the prohibitionist views of their conservative imams. (Mehtab Karim, private conversation, Pew Forum, Washington, November 2008) 
Shades of this posture are likewise evident among radical Islamist factions in mainstream states, where their arguments may dovetail with the secular imperatives of nationalists or politicians who seek an enlarged power base. Palestinian nationalism has long been pronatalist, with its politicians, journalists and poets singing the praises of their ‘demographic weapon’ against Israel. (King 2002: 386) Though secular and Islamist nationalists both extol the virtues of pronatalism, it is noteworthy that fertility rates are higher in Gaza, a Hamas bastion and stronghold of the Islamist-inspired second intifada, than in the secular, Fatah-controlled West Bank. (Fargues 2000: 469-70) Even in Turkey, where the temperature of conflict is lower, Islamist nationalists have played the pronatalism card. Prime minister Recep Tayyip Erdogan, leader of the Islamist Justice and Development Party (AKP), cut his teeth by attacking contraception and abortion to woo both nationalist and Islamist audiences. In 2002, two years before he was elected, Erdogan pulled few punches: 'To recommend to people not to procreate is straight out treason to the state,' Erdogan told a crowd gathered to celebrate the opening of an AKP office in Istanbul. 'It's a means of wanting to erase the history and the surface of the land'. Having played on nationalist registers, he moved to religion: 'Have babies,' he told the crowd. 'Allah wants it.' (Caldwell 2005)

Iranian hardline president Mahmoud Ahmadinedjad is no stranger to this issue. He is seeking to change the course of Iranian family policy, advocating renewed population growth. Criticizing Iran's below-replacement fertility rate, he wants Iran's population to grow from its current 70 million to 120 million. Along the way, he favours scaling back women's participation in the labour force to concentrate on reproduction. 'I am against saying that two children [per woman] are enough', thundered Ahmadinedjad. 
'Our country has a lot of capacity. It has the capacity for many children to grow in it. It even has the capacity for 120 million people. Westerners have got problems. Because their population growth is negative, they are worried and fear that if our population increases, we will triumph over them.' Unfortunately for this maverick, Ahmadinedjad faces an established opposition, backed by a majority of Iranians and many senior clerics. (Cincotta 2006; Tait 2006) Factionalism within the regime is intense, and popular sentiments play a role in determining which faction gains favour. Iran's quasi-democracy means that Ahmadinedjad must be mindful of his popularity, which could stay his pronatalist hand.

\section{Micro-Level Muslim Fertility}

Most Muslim governments, even those under Islamist sway - are succeeding in their family planning efforts. But there are some cautionary notes. First, Muslims - like many minorities - tend to have higher fertility when they are in the minority. (Goldscheider 1971) In Malaysia, Egypt, Lebanon or Albania, where Muslims are a comfortable majority, their fertility differs little from that of non-Muslim minorities. (Westoff and Frejka 2007) In Europe, India, Thailand, Russia, China and the Philippines, the Muslim fertility advantage over other groups is greatest. This is particularly true of ethnoreligious conflict zones like Israel-Palestine or India where a significant Muslim fertility advantage persists despite urbanisation and equivalent access to contraception. (Morgan, Stash et al. 2002; Moulasha and Rao 1999) Yet fertility rates among most Muslim minorities are also on their way down. This is particularly noticeable among 
European Muslims, whose fertility is falling toward host country levels. In Austria, the number of children expected to be borne by Muslim women over their lifetime (TFR) declined from 3.09 in 1981 to 2.34 in 2001. (Goujon, Skirbekk et al. 2006: 13) Similar trends have been observed across all of western Europe. In Switzerland, Germany and the Netherlands, Turkish-born women now have an expected fertility rate of less than two children. This reflects the decline in Turkey itself. Pakistani and Somali fertility is highest among European Muslims, followed by North Africans and Turks, but all are falling fast. (Westoff and Frejka 2007)

A central argument here is that fertility differences rooted in economic underdevelopment or unselfconscious, 'traditional' cultural differences (i.e. Protestant v. Catholic, Muslim v. Christian) will fade in the absence of ethnoreligious conflict. Those who merely happen to be Muslim but lack a mobilised commitment to political Islam will experience declining fertility as their economic situation develops and access to family planning improves. On the other hand, differences based on either mobilised Muslim ethnic identity (i.e. Palestinian, Moro) or religious intensity/conservatism (i.e. political Islam) will endure or widen as societies enter the second demographic transition. Religious fertility among Muslims will be driven increasingly by conservative subgroups and individuals rather than states, because states are mindful of secular considerations (i.e. reducing dependency ratios and pressure on resources) whose imperative points toward family planning.

To investigate the emerging vista of second demographic transition Islam, we shall redirect our attention to individual-level data. One of the few attempts to examine the link between Islamist religious beliefs and fertility comes from a study by Eli Berman 
and Ara Stepanyan in 2003 which 'investigates every data source the authors could find on radical Islamic communities' to examine Islamist fertility. (Berman and Stepanyan 2003: 1) The datasets compiled came from disparate corners of the Muslim world: Indonesia, rural Bangladesh, rural parts of the Indian states of Uttar Pradesh and Bihar, and Cote D'Ivoire in West Africa. The principal indicator of Islamism was whether children were sent to madrassas, or Islamic religious schools. Some 13 percent of Indonesians sampled attended madrassas, but the proportion attending elsewhere was only about 2 to 3 percent. The authors found that 'fertility is higher and returns to education are generally lower among families that send children to Islamic schools'. (Berman and Stepanyan 2003: 30)

However, the model coefficients for Islamic schooling were much weaker than those for overall education and were strongest in the Indian states of Uttar Pradesh and Bihar. Elsewhere (Indonesia, Bangladesh, Cote D'Ivoire), attendance at madrassas proved significant, but only in some models. Figures 6 and 7 show that the Islamist fertility premium varies considerably between different societies but is nowhere greater than about 30 percent. These results confirm that Islamism is a significant determinant of fertility, but not to such an extent as to suggest imminent growth in the Islamist population on the scale of the ultra-Orthodox Jews in Israel who have a 3:1 fertility advantage over non-Orthodox Jews. (i.e. Fargues 2000) Let us also bear in mind the generally small numbers (2-3 percent) of Islamists in these samples, though the proportion of those sympathetic to fundamentalist Islam may be much wider than the madrassa-attending population. A better point of comparison therefore is the United States, where the fertility premium of conservative over mainline Protestants appears to 
be very similar to that between Islamist and non-Islamist families. (Roof and McKinney 1987) The 15-20 percent fertility advantage enjoyed by religious west Europeans over their nonreligious fellow citizens is also of similar magnitude. (Kaufmann 2007) They intimate that demographically-driven radical change may occur in Islamic countries, but over a period of a century or more rather than a generation.

\section{Figure 6.}

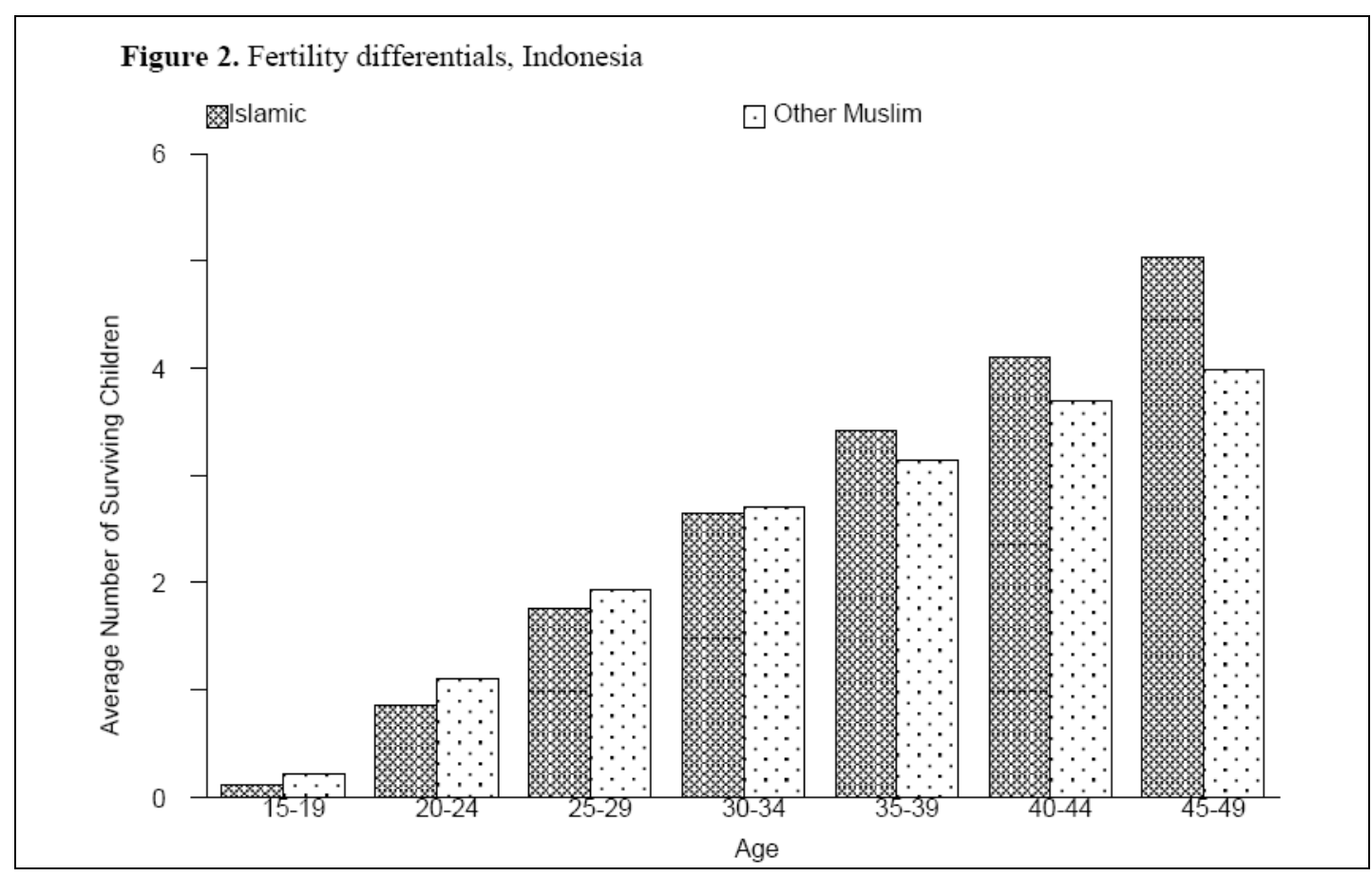

Source: Berman and Stepanyan 2003 


\section{Figure 7.}

Figure 4. Fertility differentials, India, rural UP\&B

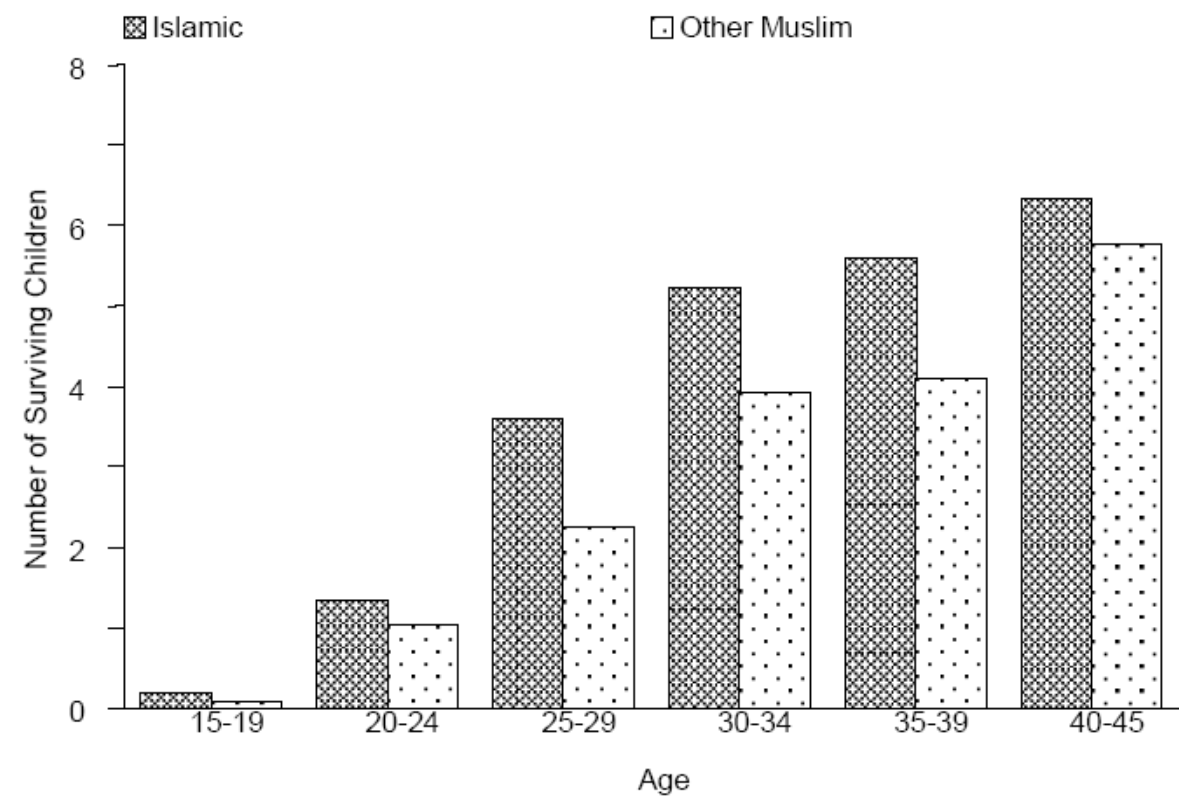

Source: Berman and Stepanyan 2003

What of Islamism? The first thing to bear in mind is Ernest Gellner's classic view that puritanical Islam is an advanced phenomenon that tends to fan out from urban centres of learning. It is in many respects a modernizing movement that confronts the more heterodox folk Islam of the countryside. (Gellner 1981) When it acts as a competitor to rural, sufi traditionalism, we would not expect Islamism to be associated with higher fertility. This appears to be the case in Iran, where traditionalist (but less Islamist) ethnic peripheries of Kurds and Baluchis have the highest fertility while more Islamist Persian districts are no more fertile than average. (Abbasi-Shavazi, Hossein-Chavoshi et al. 2007) In Turkey, at province level, Islamic religiosity seems unrelated to fertility. Instead, higher fertility seems to be related to illiteracy rates and, to a lesser extent, higher 
unemployment rates. Table 1 and figure 8, for example, show that provinces which support the ruling Islamist AKP are more religious (in terms of religious students and mosques per capita) and have more married people and fewer divorcees, but are no more fertile than provinces like Istanbul which are less keen on the AKP. ${ }^{4}$

\section{Figure 8.}

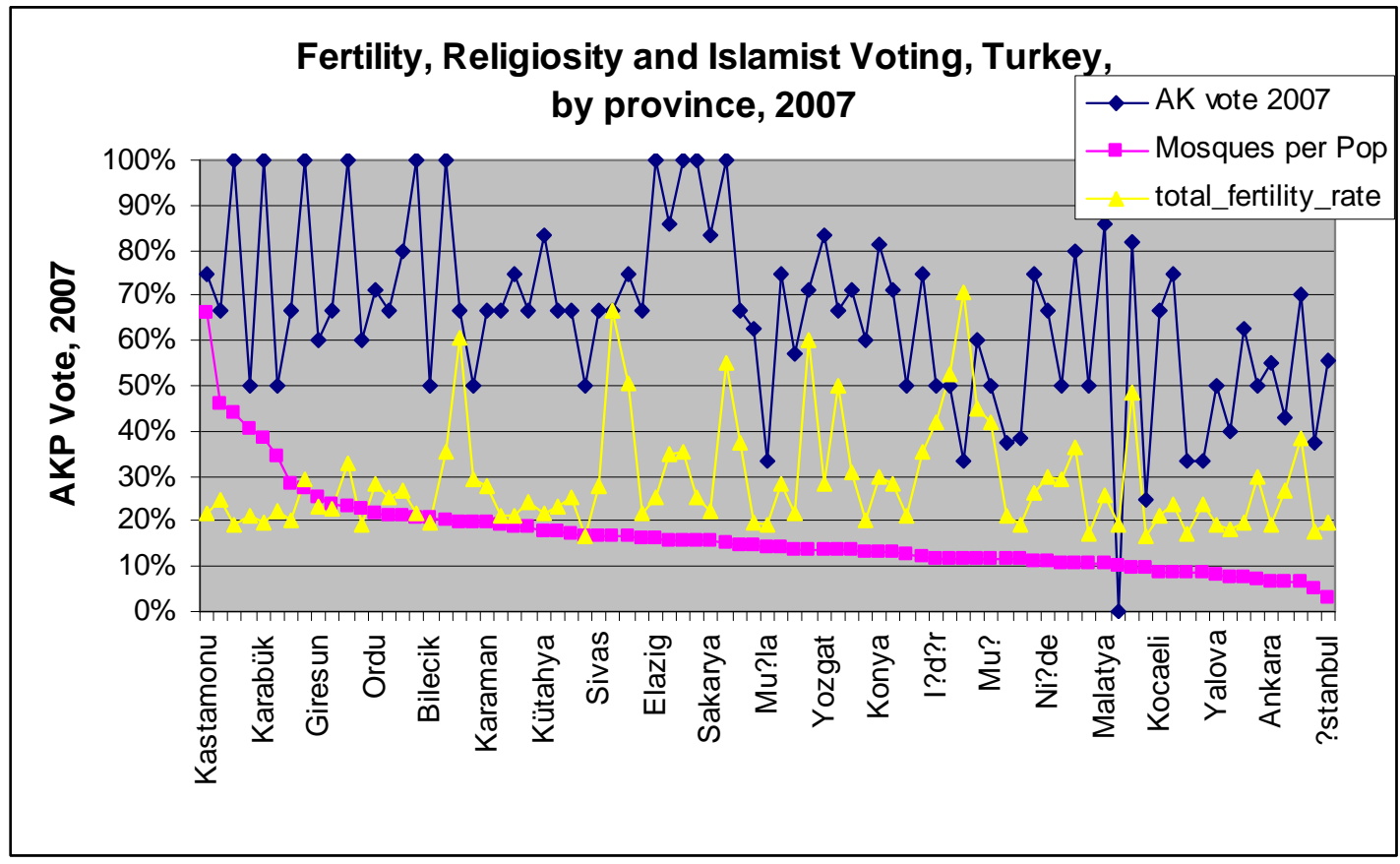

Source: Author's calculations; Turkish National Statistics Agency.

Table 1. Predictors of Voting for AK (Islamist) Party, Turkey, 2007

\begin{tabular}{|l|l|l|l|}
\hline & Coefficient (B) & S.E. & t-statistic \\
\hline Divorce Rate & $-19.68^{* * *}$ & 4.39 & -4.48 \\
\hline Elderly Dependency Ratio & $-0.02^{* *}$ & 0.01 & -3.47 \\
\hline Mosques per Capita & $67.59^{* *}$ & 23.89 & 2.83 \\
\hline Sex Ratio & $-0.01^{*}$ & 0.00 & -2.18 \\
\hline Votes for Minor Parties & $-0.65^{* * *}$ & 0.09 & -7.3 \\
\hline Infant Mortality Rate & $0.00^{*}$ & 0.00 & -2.1 \\
\hline constant & $1.76^{* * *}$ & 0.27 & 6.5 \\
\hline $\mathbf{R}^{\mathbf{2}}$ & $\mathbf{. 6 5 8}$ & & \\
\hline $\mathbf{N}$ & $\mathbf{8 1}$ & & \\
\hline
\end{tabular}

$* \mathrm{p}<.05 ; * * \mathrm{p}<.01 ; * * * \mathrm{p}<.001$ 
However, as with the national-level of geography, things change when we focus on individuals. True, bivariate analyses of demographic and health surveys find that traditionalism, as measured by arranged marriage, payment of a dowry, membership in a patrilocal family, rural residence and illiteracy, is the most important determinant of fertility rates. Kurdish ethnicity is also associated with higher fertility rates. ${ }^{5}$ (Yavuz 2005) A recent study of contraceptive use in Iran, based on a 2002 Iranian fertility survey, likewise finds that attitudinal variables are much weaker predictors of the odds of using contraception than education levels. Further tests using a battery of seven attitudinal items related to women's employment find little or no significant relationships between gender role traditionalism and contraceptive use. The authors therefore suggest that secularisation and 'modern' attitudes are not a factor in Iranian contraceptive behaviour. (Abbasi-Shavazi, Hossein-Chavoshi et al. 2007)

Nevertheless, censuses and fertility surveys, which are widely available for most Muslim countries, are notoriously poor at detecting the influence of religion because they neglect measures of religious intensity (i.e. belief, attendance). The World Values Survey (WVS) provides an exception in that its recent 1999-2000 wave surveyed a number of largely Muslim countries for the first time. This allows us to correlate fertility with specific indices of religious intensity. This is clear in the WVS' 1999-2000 wave, the only individual-level survey that permits us to focus on how religiosity and Islamist attitudes are linked to higher fertility. Multivariate manipulation of this survey shows that religious Turks are significantly - if modestly - more fertile than nonreligious Turks. ${ }^{6}$ We shall see that this finding is especially true of urban areas. As second demographic 
transition theory suggests, it is only when traditionalism fades, material constraints diminish and people's ideology and fertility are no longer inherited that we would expect the religiosity-fertility nexus to strengthen.

Let us consider the WVS findings in greater detail. The WVS asked 8500 respondents in seven Islamic countries a number of religiosity questions (participation, attendance, belief) as well as whether they agreed that the state 'should implement Shari'a only' as the law of the land. The proportion of Muslims favouring Shari'a as the exclusive law of the land was roughly two-thirds, ranging from over 80 percent in Egypt and Jordan to around half in Indonesia, Nigeria and Bangladesh. Responses, restricted to Muslims only, were highest in the Middle East and North Africa, and lower in Asia and subSaharan Africa. (See figure 9)

\section{Figure 9}

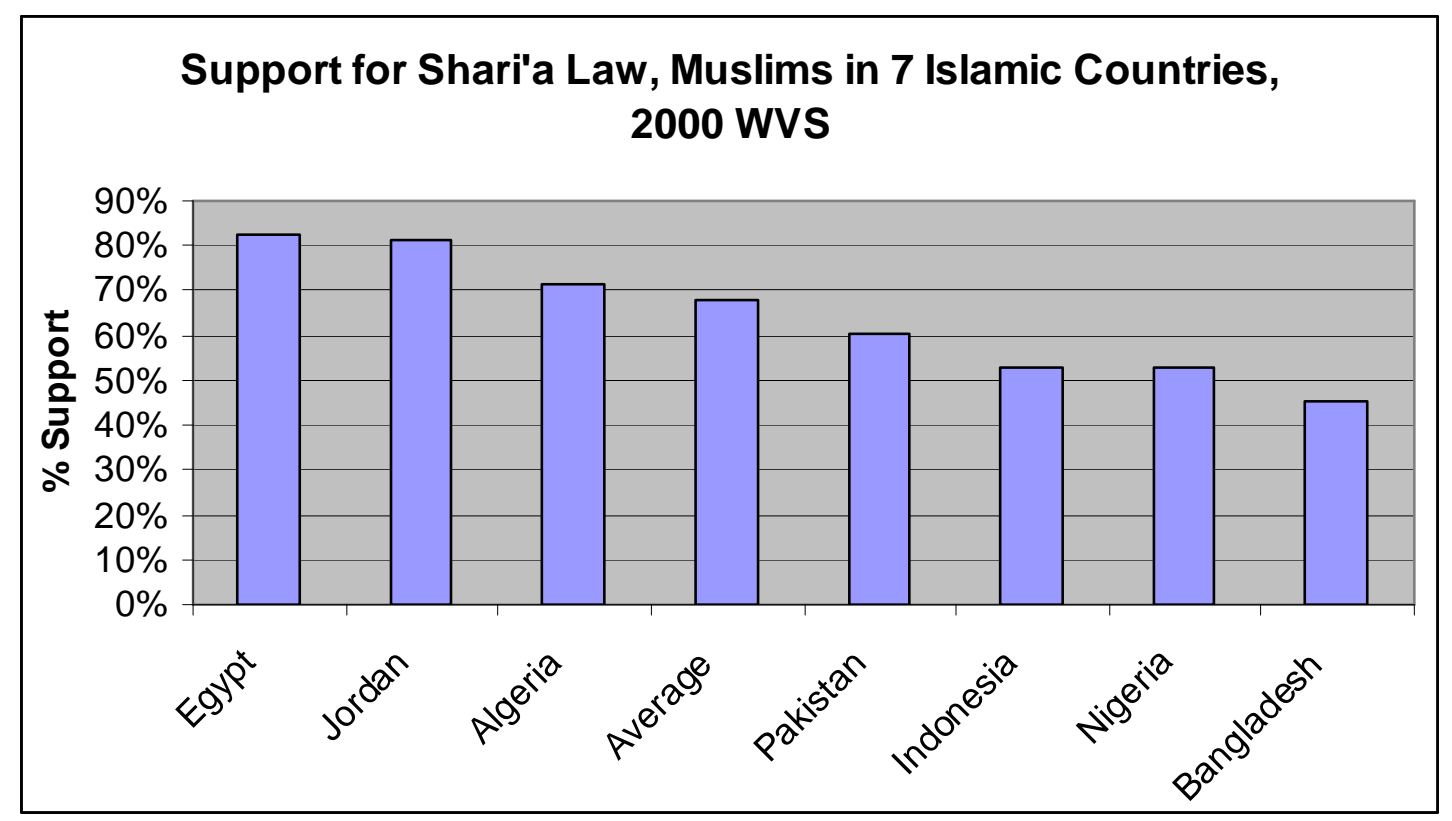

Source: WVS. N=8544 cases. 
A glance at the Shari'a question crosstabulated with fertility shows some interesting patterns. In Egypt, for example, we find that those with lower fertility are more likely to disagree with the idea that Shari'a should be implemented as the law. (See figure 10)

\section{Figure 10}

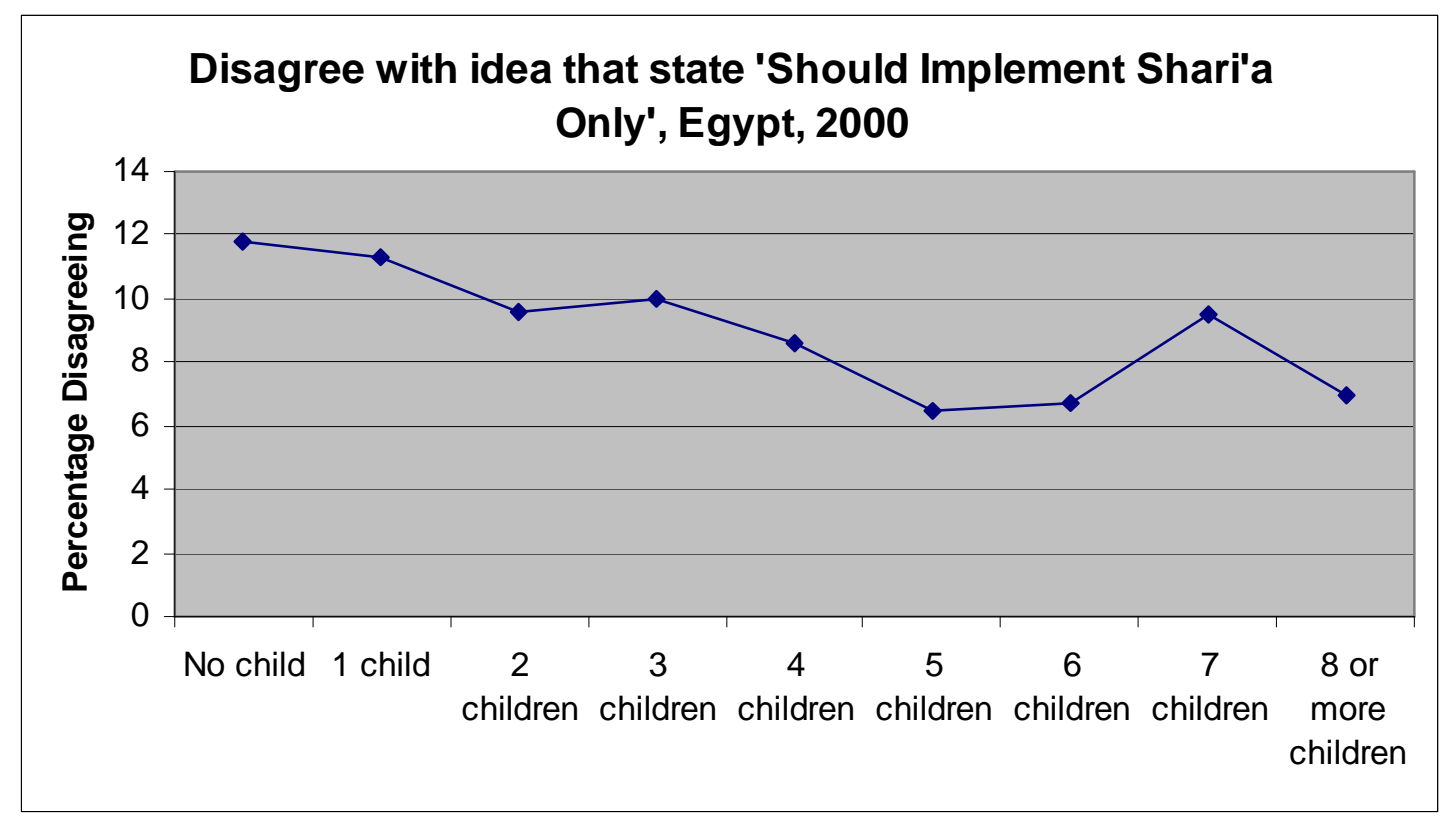

Source: WVS 1999-2000. N = 2113 respondents. 
In the wider universe of majority-Muslim countries where this question was asked (Bangladesh, Indonesia, Jordan, Pakistan, Nigeria, Egypt, Algeria), a similar pattern could be discerned. Yet we know that fertility rates are falling in many of these countries due to urbanisation and education. It could be the case that education and a shift of population to the cities simultaneously lowers fertility and the belief in the appropriateness of Shari'a law. Or perhaps older people, who are more likely to have completed their fertility and/or had more children, are more supportive of Shari'a law. On its own, therefore, our finding that supporters of Shari' a law have higher fertility could be an artefact of unspecified factors like age, education and urbanisation. Urban, educated or younger individuals in Muslim societies might be less supportive of Shari'a and also prefer smaller families.

Let us consider each of these counter-explanations, beginning with rural-urban geography. When we break up the sample into rural and urban residents, we find that the pattern of Islamist fertility holds. Moreover, as figure 11 shows, the effect seems more marked among urban populations. Among city dwellers, fertility is almost twice as high (3.2 v. 1.8) amongst the most pro-Shari' a sector of opinion than amongst those least in favour, whereas in rural areas, the ratio is less than 3:2. We might hypothesize that in rural, underdeveloped areas, religious beliefs take a back seat to material realities, such as access to family planning or the economic benefits of larger families, in discriminating between the more and less fertile. In urban areas, where economic incentives for children are lower and costs higher while birth control technology is more widely available, it may be the case that values are a better discriminant of reproductive behaviour. Urban areas 
also tend to be seats of puritanical Islamic learning as against the more sufi, folk-based religion of the countryside. (Gellner 1981) Since the countryside is a repository of traditional (i.e. natalist) attitudes to fertility, but is weak in its Islamism, the only way we might spot an emerging relationship between Islamism and fertility is by restricting our gaze to urban areas. Such behaviour could encompass a range of issues, including the nature of appropriate gender roles, the decision to use contraception or other forms of family planning, and whether to have children for pronatalist religious reasons. Indeed, it is well-known that political Islam has drawn strength in urban areas like the Nile Delta in Egypt, and is associated with migration to the cities. (Munson 2001; Kepel 2002; Halliday 2000)

\section{Figure 11}

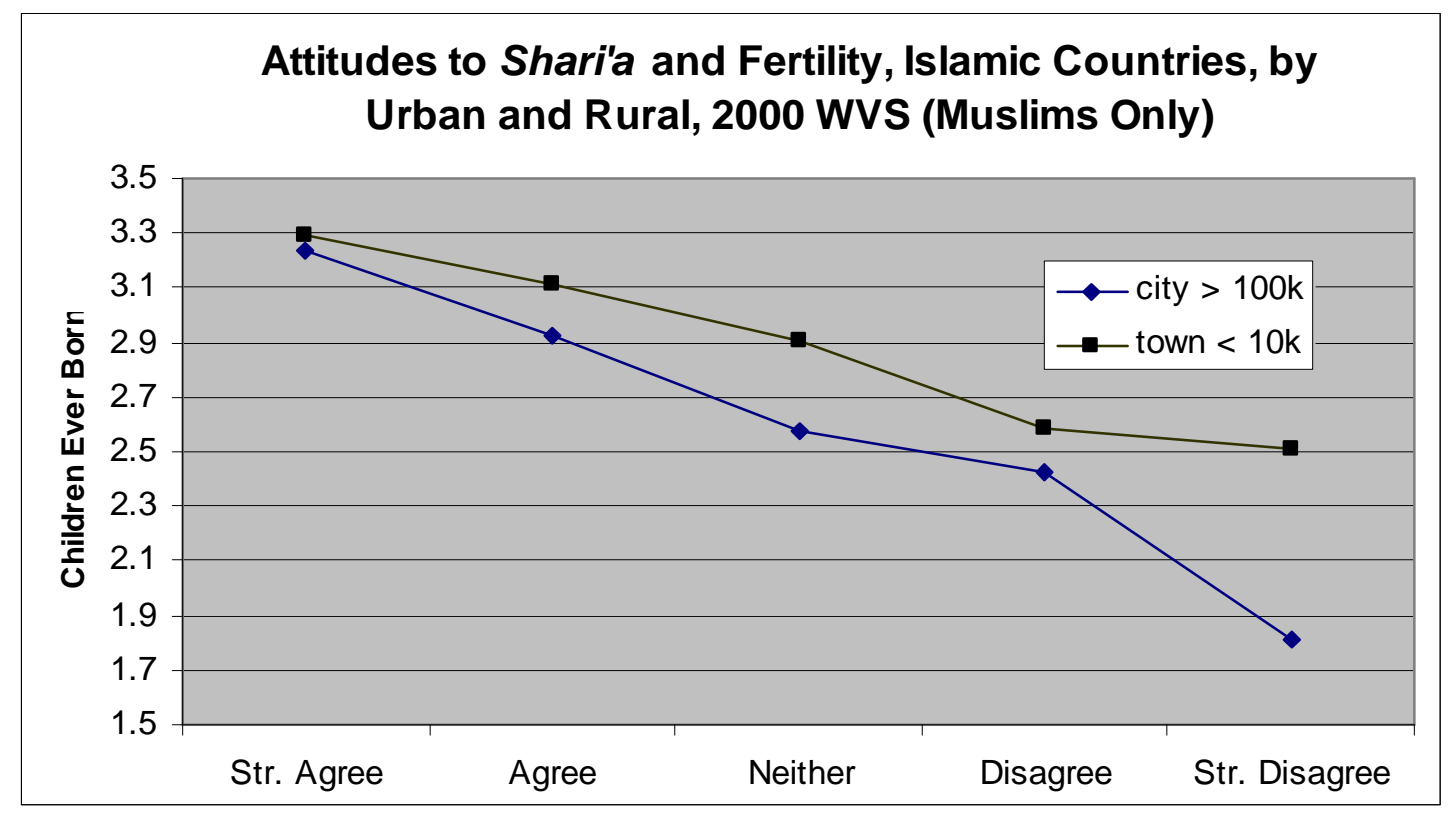


Source: WVS 1999-2000. N = 2796 respondents in towns under 10,000 and 1561

respondents in cities over 100,000. Asked in Algeria, Bangladesh, Indonesia, Jordan,

Pakistan, Nigeria and Egypt.

WVS evidence for the seven countries where the question on Shari'a law was asked seems to support some findings of demographic and health surveys, but not others. For instance, while there seems to be a large fertility gap of some 1.5 children between those with less than secondary and those with greater than secondary education (supporting findings from health surveys), there remains a distinct relationship between support for Shari'a and higher fertility. This seems to hold for both the well-educated and poorly-educated strata of the population, as shown in figure 12 .

\section{Figure 12.}

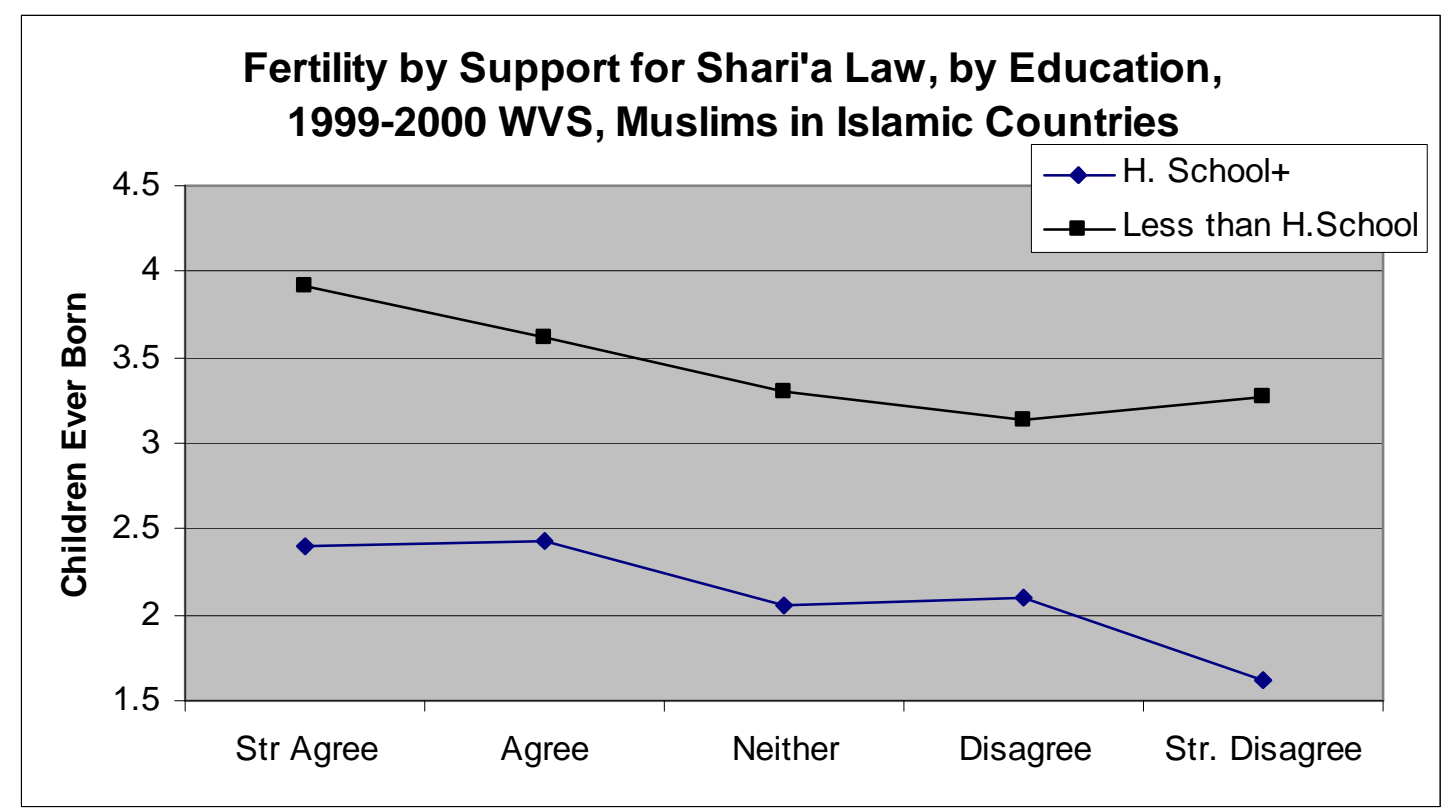


Source: WVS 1999-2000. N = 1649 respondents with High School or More, 3318 respondents with Less than High School. Asked in Algeria, Bangladesh, Indonesia, Jordan, Pakistan, Nigeria and Egypt.

In order to test these relationships more robustly, we employ a multilevel model of fertility based on the WVS.

\section{Data and Methods}

Data are drawn from the 1999-2000 waves of the World Values Survey (WVS). Aggregate data comes from World Bank Development Indicators for the relevant year, except for country religiosity which has been computed by taking the arithmetic mean of the individual responses to the WVS question 'are you a religious person' and apportioning 'not religious' and 'atheist' responses into a nonreligious total. The WVS also asks a question on support for Shari'a law in a more restricted range of countries. The multi-level logistic regressions use national-level data as level 2 regressors and WVS data as level 1 estimators. All analysis uses Stata 7.0. The regression sample only consists of women as is standard practice in demography. For previous tables, however, we have included males since male fertility is also of interest to us. 


\section{Individual Variables, from the WVS:}

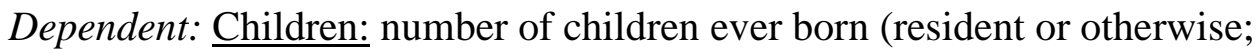

\section{Independents:}

Marital Status: married (1), living together as married (2), divorced (3), separated (4), widowed (5), single/never married (6), divorced, separated or widow (7)

Age: years;

Income: constant Year 2000 US\$;

Education: highest level of education completed (8 levels arrayed ordinally;

Shari'a: 'Now, what's your opinion about a good government? Which of the following characteristics a good government should have?' A: 'It should only implement Shari'a's laws.' Strongly Agree (1), Agree (2), Neither (3), Disagree (4), Strongly disagree (5). Question asked in Algeria, Bangladesh, Indonesia, Jordan, Pakistan, Nigeria and Egypt. Religious Belief: Factor produced from five questions related to religious belief. See appendix 1 for details. Question asked in Algeria, Bangladesh, Indonesia, Jordan, Pakistan, Nigeria, Egypt, Azerbaijan, Bosnia, Iran, Morocco, Turkey, Uganda and Tanzania.

Religiosity: Are you a religious person? Yes (1), No (2), Committed Atheist (3). Question asked in Algeria, Bangladesh, Indonesia, Jordan, Pakistan, Nigeria, Egypt, Azerbaijan, Bosnia, Iran, Morocco, Turkey, Uganda and Tanzania.

Religiosity (Binary): Are you a religious person? Yes (1), No (0). No is a recoding of 'No' and 'Atheist'. 
Income category: lowest to highest

National Pride: How Proud are you of your nation? Very Proud (1), Quite (2), Not

Very(3), Not at all(4)

We begin our modelling by regressing individual female fertility on measures of religiosity, Shari'a support and the standard control variables listed above. Model 1 includes the Shari'a question (limited to six countries), and Model 2 only includes the religious traditionalism question (asked in thirteen countries) and so generates a sample almost twice as large. Yet the coefficients and their significance do not show major differences between the two models. The results, shown in table 2 show some expected findings, and some less expected.

Table 2. Regression Coefficients on Individual Fertility, Muslim Women in Islamic Countries, 1999-2000 WVS

\begin{tabular}{|l|l|l|l|l|}
\hline & Model 1 & & Model 2 & \\
\hline Marital status & $-.280^{* * *}$ & .022 & $-.265^{* * *}$ & .014 \\
\hline Age & $.080^{* * *}$ & .003 & $.079^{* * *}$ & .002 \\
\hline $\begin{array}{l}\text { Traditional Religious } \\
\text { Beliefs }\end{array}$ & $.415^{* * *}$ & .108 & $.303^{* * *}$ & .054 \\
\hline Shari'a Only & $.086^{* *}$ & .028 & & \\
\hline Individual Education & $-.183^{* * *}$ & .016 & $-.190^{* * *}$ & .011 \\
\hline Personal Income & -.030 & .016 & -.014 & .012 \\
\hline Country Religiosity & $-2.017^{* * *}$ & .238 & $-.871^{* * *}$ & .131 \\
\hline $\begin{array}{l}\text { Country Secondary } \\
\text { School Enrollment \% }\end{array}$ & $.019^{* * *}$ & .002 & $.017^{* * *}$ & .001 \\
\hline $\begin{array}{l}\text { Country GDP per } \\
\text { capita }\end{array}$ & $-2.222^{* * *}$ & .494 & $-1.524^{* * *}$ & .270 \\
\hline Country Population 65+ & $-.464^{* * *}$ & .060 & $-.596^{* * *}$ & .047 \\
\hline constant & $1.910^{* *}$ & .594 & $1.861^{* * *}$ & .389 \\
\hline $\mathbf{R}^{2}$ & .403 & & .432 & \\
\hline $\mathbf{N}$ & 2682 & & 4828 & \\
\hline
\end{tabular}

$* \mathrm{p}<.05 ; * * \mathrm{p}<.01 ; * * * \mathrm{p}<.001$

NB: Country Total Fertility Rate was dropped from the analysis due to problems with multicollinearity. Note that the question on Shari'a was only asked in six countries while that on religious belief was asked in thirteen countries. Its coefficient sign has been reversed here for easier interpretation. See methodology section for the list of countries. 
Marital status and age are standard controls which show similar strong relationships to individual female fertility in all countries. Otherwise, education, at both the individual and country levels, has the strongest effect, along with the proportion of elderly people in a society (an indirect measure of a country's fertility and age structure). ${ }^{7}$ Higher GDP per capita is related to lower individual fertility. However, the story is not purely structural. We see, for example, that religious traditionalism (with respect to hell, heaven, sin, afterlife) and approval of Shari'a law are significant predictors of fertility.

Traditional religious belief shows a robust effect in these models, and support for Shari'a law - a measure of political Islamist attitudes - is also a significant predictor of fertility at the $p<.01$ level. Tests with religious attendance show no significant effects when a control for religious traditionalism remains, but attendance emerges as significant when belief is removed from the model. Questions which measure female respondents' view of whether nonreligious people are fit for public office or whether it is better for political leaders to be 'strongly religious' are also significantly correlated with fertility (though slightly more weakly than is true for the Shari'a question).

Few surveys which ask detailed questions on Muslim political attitudes include items on fertility. However, a recent survey of 18-25 year-olds in Egypt and Saudi Arabia asked respondents to specify whether they belief their countries would benefit from lower fertility. ${ }^{8}$ The survey also asked about political Islamist attitudes. Figures 13 and 14 below show that in the case of both support for Shari'a law ${ }^{9}$ and an Islamic government ${ }^{10}$, Islamists are more likely to favour pronatalist policies than non-Islamist Muslims. For instance, those who feel that the government should implement Shari'a or that an Islamic 
government where the religious authorities have 'absolute power' is 'very good' only favour lower fertility by a 60:40 ratio, compared to 90:10 among those who view Shari'a as 'less important' or an Islamic government as 'fairly bad'. ${ }^{11}$ These data do not directly tap fertility behaviour, but are revealing in that $18-25$ year-olds are likely to be at the beginning of their fertility odysseys and thus offer a potential glimpse of what the future may hold.

\section{Figure 13.}

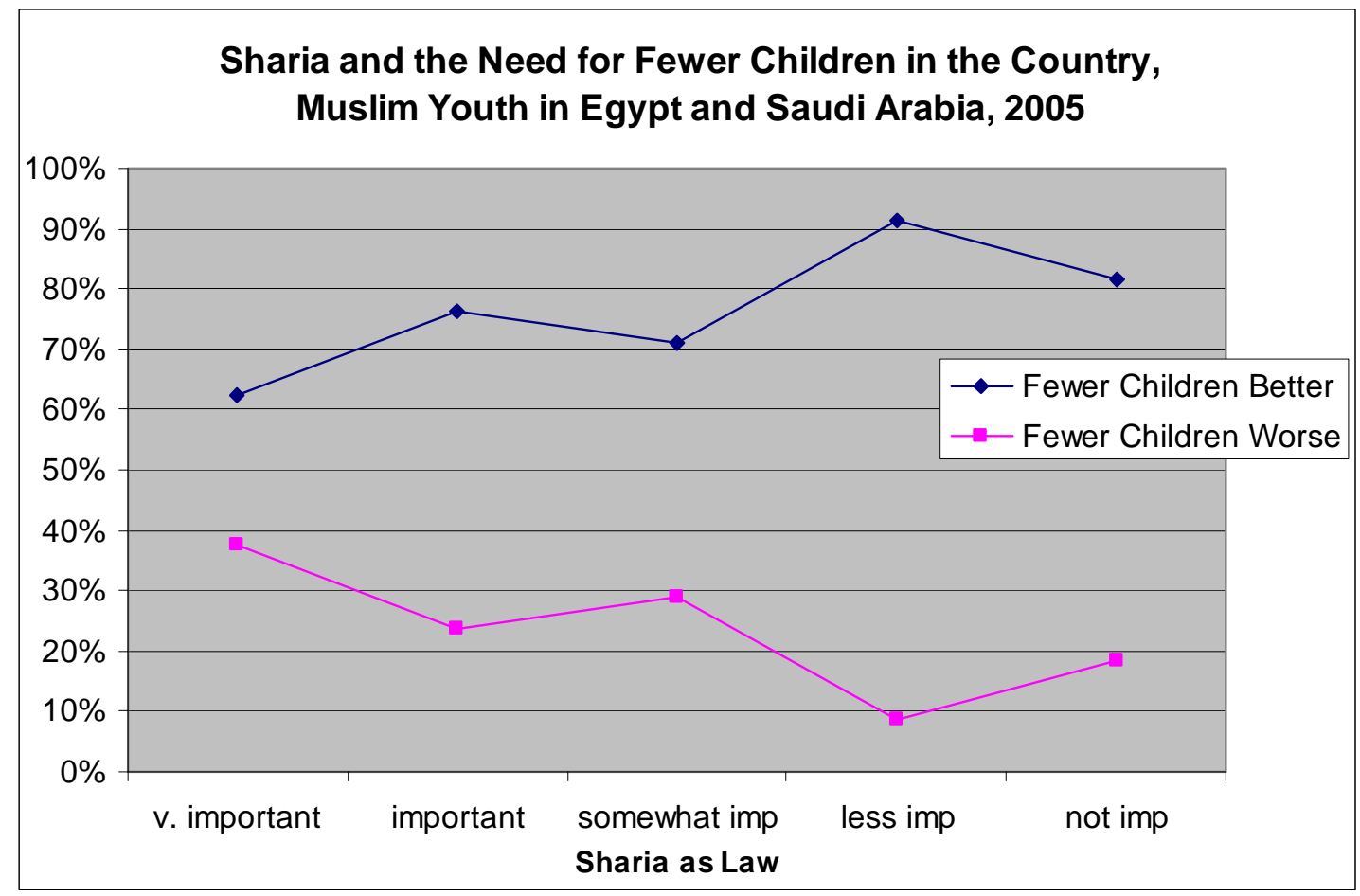

Source: Calculated from (Moaddel, Karabenick et al. 2005) 


\section{Figure 14.}

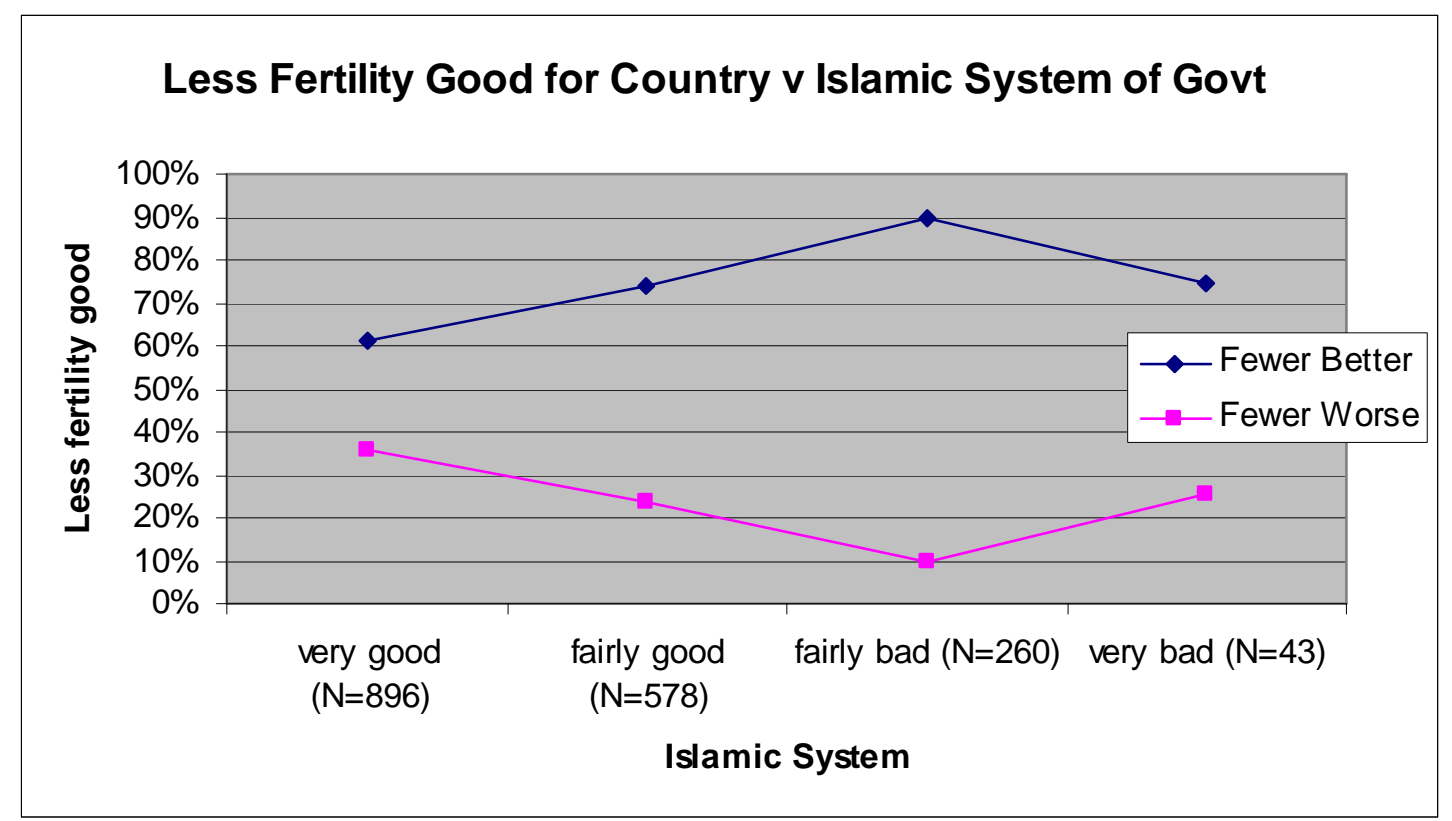

Source: Calculated from Moaddel et al. 2005

Evidently there is an association between conservative religious views and pronatalism among Muslim politicians and the public. This extends from thoughts to concrete behaviour, with Islamist Muslims maintaining significant higher fertility than other Muslims, especially in urban contexts. This is critical since second demographic transition theory predicts that value choice should bulk larger in the more modern setting of the city, where contraception is widely available and economic incentives would ordinarily incline people to choose smaller families. Urban populations of developing regions are expected to increase from 43 percent of the total today to 67 percent in 2050 . (Goldstone 2009) In addition to assimilating rural Muslims into urban fundamentalism, this large-scale population flow will usher more of the Muslim world into the second demographic transition. Religion will become increasingly pivotal in determining fertility 
outcomes, leading to fundamentalist growth, i.e. the demographic radicalization of Islamic societies.

Conservative Islam and Security

There is not space here to summarize the vast literature on conservative Islam and security other than to reiterate that, as with other faiths, Islamist militants are selective in their interpretation of their sacred texts: the Koran and hadith, not to mention sharia and Islamic history. While the resurgence of conservative Islam in the post-1967 period (manifested in the rising popularity of veiling among young women and increased mosque-building) has been accompanied by a rise of Islamist terrorist groups, much of this movement has been peaceful. Secular violence in the Muslim world, associated with Marxist groups like the PLO, has subsided. Every decade since 1940, roughly twenty civil wars costing over 1000 deaths per year have flared, and there is little sign of a general increase. However, the religious proportion of these wars has increased, and, in turn, the Muslim slice of that religious violence has grown. Indeed, Islam is implicated in 81 percent of the 42 post-1940 civil conflicts involving religion, and 90 percent of the ten civil wars fought within a single religion. Religious civil wars tend to be more intractable and 'zero-sum' in nature than other forms of civil conflict, and in this sense, more prolonged. (Toft 2007) Islamic terrorists also virtually own the field of transnational religious terrorism.

Many have rightly emphasized the anti-western, quasi-nationalist nature of contemporary political Islam, which extends to the motivation of Islamist suicide 
bombers. (Zubaida 2004; Pape 2005) Even the doctrine of takfir (denoting Muslims who have strayed from the fundamentals of Islam) which militant Islamists have deployed to justify the killing of Muslim civilians, can be interpreted as an indirect attack on the West, and hence a species of nationalist ressentiment. (Appleby 2008) But this cannot deflect the fact that the bombers, radical clerics and planners are true believers who are willing to die or go to prison for their beliefs. Most Islamic fundamentalists are not violent, but all violent Islamists are fundamentalists. Given that all Islamist terrorists are literalist in their beliefs (albeit selective in their interpretation of their holy texts), it is hard to avoid the conclusion that the growth of religious fundamentalism in the Muslim world will prompt a rise in religious conflict and security threats. This may be counterbalanced by a decline in secular (i.e. Marxist, secular nationalist) sources of violence, but one could equally well imagine a more unstable, bloody security environment. In this sense, Islam's demographic radicalization, which will increase the proportion of conservative Muslims as Muslim societies modernize, presents a challenge for long-term security in the Middle East, West Asia and beyond. Even if security challenges do not become more serious, a more theologically conservative Muslim world will prove markedly less receptive to social liberalism and capitalism, two critical pillars of the 'End of History'. Only a highly illiberal variant of democracy, perhaps represented by parties such as SCIRI in Iraq, the Muslim Brotherhood in Egypt, Hizbullah in Lebanon or Hamas in Palestine will prove to be compatible with Islamic fundamentalism. (Zakaria 1997) 
Conclusion

In the context of the second demographic transition, religious women tend to have more children than non-religious women. Conservative religious families are larger than theologically modernist families. This is especially so today because the demographic transition has removed the material constraints (high mortality, absence of contraception, agricultural need for labour) which underpinned a high fertility-high mortality population equilibrium. Today, values play a more important role in fertility behaviour, throwing the contrast between religious pronatalism and secular low-fertility individualism into relief.

Over several generations, this process can lead to significant social and political changes. Early Christianity's exponential rise during its gestation period from 30 to 300 A.D. has been traced to its superior demography (fertility, mortality and female sex ratio), which maintained a rate of growth similar to contemporary Mormonism: 40 percent per decade. For Christians, this led to a jump from 40 converts to 6 million inside three centuries. (Stark 1996) Christianity became the religion of an empire and a continent. In the United States, conservative sects increased their share of white Protestantism from roughly a third to two-thirds during the twentieth century - largely on the back of higher fertility. On the other hand, sects like the Shakers and Cathars, which permitted entry only through conversion, rapidly faded from the scene. Demographic religious revival is a medium and long-term phenomenon, but awareness of shifting population composition can lead to political soul-searching and instability well before the full impact of demographic change takes place. This is clear in ethnically-tense societies like Israel, Northern Ireland, Bosnia, Lebanon, Cote D’ Ivoire or Assam. 
We have shown that demographic radicalization is most advanced in Israel and the Jewish diaspora, where ultra-Orthodox Jews are poised to become a majority of the Jewish population soon after 2050. In the United States and Europe, fundamentalist Christians have markedly higher fertility than others, but this advantage is typically in the half-child range (roughly a 25 percent advantage) rather than the 100-200 percent fertility advantage over others enjoyed by the Haredim within global Jewry. This means that change in the West will take place over generations rather than in the space of a decade, as in the Judaic world. Immigration is another driver of conservative religious growth in Europe, and will have a substantial impact on the re-sacralisation of this once secular continent by 2050. In North America, only small Anabaptist sects like the Hutterites (population 50,000), Amish and some Mennonites maintain a Haredi-like fertility premium, and will emerge as significant groups in rural areas over several generations. Mormons, a much larger group, have intermediate fertility, and outnumber Jews among Americans born after 1945. Conservative Christians as a whole will have a stronger presence in the white America of 2050 than they do today, and a more powerful national voice if they can forge alliances with traditionalist Hispanic Catholics, as shown in the recent success of Proposition 8 (anti-same sex marriage) in California.

In the Muslim world, Islamic fundamentalism is associated with urban centres of learning, and hence remains as much a sign of modernity as a marker of traditionalism. Even so, Islamism is associated with pronatalism, whether in the speeches of politicians or the views of the masses. Among individuals - especially in urbanised, modern contexts - Islamism predicts significantly higher fertility. As Muslim society urbanises, we would expect Islamic fundamentalism to reap a demographic dividend as more 
conservative individuals choose larger families. However, the magnitude of demographic radicalization in the Muslim world seems more in keeping with the American and European pattern than the Jewish one. This means that significant change will take half a century, as opposed to the situation in Israel, where startling changes have occurred, and will occur, within the span of a decade.

Daniel Bell defined modernisation as a liberalisation of culture, democratisation of politics and rationalisation of the economy. (Bell [1976] 1996) The endpoint of this juggernaut, the 'End of History', is presumed to be liberal democracy and mixed capitalism, a formula amenable to fine-tuning, but not to radical transformation. Neither crime, a decaying work ethic (as Bell prophesied) nor economic collapse (as Marx predicted) have seriously shaken this model. However, societies with a relativistic, individualist, acquisitive outlook are demographically vulnerable. Only if it can assimilate the children of those with demographically sustainable outlooks can the liberal capitalist model survive. This is a tall order given the exhaustion of 'secular religions' like Utopian socialism or revolutionary nationalism that appeal to religious individuals' sense of the transcendent. Instead, a new synthesis of modern technology, illiberal democracy and conservative religion may emerge from the ashes of the 'End of History' to surmount its demographic contradictions.

\section{$\underline{\text { References }}$}

Abbasi-Shavazi, M. J., M. Hossein-Chavoshi, et al. (2007). Family Change and Continuity in the Islamic Republic of Iran: Birth Control Use Before the First Pregnancy, Duke University.

Adsera, A. (2004) Marital Fertility and Religion: Recent Changes in Spain,' IZA Discussion Paper 1399 (University of Chicago: Population Research Center). 
Appleby, S. (2008). Analyzing Religious Trends - An Overview. INR-NIC Global

Religious Trends: Implications for the United States (conference paper). Washington, DC.

Ben David, D. (2007). The Moment of Truth. Ha'aretz.

Berger, P. L. (2008). Max Weber is Alive and Well, and Living in Guatemala: The Protestant Ethic Today. Weatherhead Center, Harvard.

Berghammer, C., D. Philipov, et al. (2006). Religiosity and demographic events: a comparative study of European countries. paper delivered at European Population Conference (EPC), Liverpool, 2006.

Berman, E. and A. Stepanyan (2003) Fertility and Education in Radical Islamic Sects: Evidence from Asia and Africa. NBER working paper

Blackwell, T. (2008). Death for birth control: Taliban targets Kandahar health-care workers. National Post.

Bruce, S. (1998). Conservative Protestant Politics. Oxford, Oxford University Press.

Bruce, S. (2002). God is Dead. Oxford, Blackwell.

Caldwell, C. (2005). 'The East in the West'. New York Times Magazine.

Cincotta, R. (2006). "Prospects for Ahmadinejad's Call for More Rapid Population Growth in Iran." Working Paper, National Intelligence Council.

Cleland, J. and L. Lush (1997). "Population and policies in Bangladesh, Pakistan " Forum for Applied Research and Public Policy 12: 46-50.

Coleman, D. (2006). "Immigration and Ethnic Change in Low-Fertility Countries: A Third Demographic Transition." Population and Development Review, September 32(3): 401-46.

Fargues, P. (2000). "Protracted National Conflict and Fertility Change: Palestinians and Israelis in the twentieth century." Population and Development Review 26(3): 441-482.

Fiorina, M., S. Abrams, et al. (2005). Culture War? The Myth of a Polarized America. New York, Pearson Longman.

Frejka, T. and C. F. Westoff (2006). Religion, religiousness and fertility in the U.S. and in Europe. Rostock, MPDR Working Paper WP-2006-013.

Gellner, E. (1981). Muslim Society. Cambridge, Cambridge University Press. 
Goldscheider, C. (1971). Population, Modernization and Social Structure. Boston, LittleBrown.

Goldstone, J. (2007). Flash points and tipping points: Security Implications of Global Population Changes, 2005-2025. Woodrow Wilson Center, Washington, DC

Goldstone, J. (2009). "Population Movements and Security." Working Paper.

Goujon, A., V. Skirbekk, et al. (2006). New Times, Old Beliefs: Projecting the Future Size of Religions in Austria', VID Working Papers 01/2006 (Vienna: Vienna Institute of Demography)

Graham, D., M. Schmool, et al. (2007). Jews in Britain: a snapshot from the 2001 census. I. f. J. P. R. (JPR). London, JPR.

Green, J. C., M. J. Rozell, et al., Eds. (2006). The Values Campaign? The Christian Right in the 2004 Elections. Washington, D.C., Georgetown University Press.

Guth, J. (2008). "Religion in the 2008 Election." Working Paper, Furman University.

Guth, J., L. A. Kellstedt, et al. (2005). Religious Mobilization in the 2004 Presidential Election. American Political Science Association. Washington, DC.

Hackett, C. (2008). Religion and Fertility in The United States: The Influence of Affiliation, Region, and Congregation. Austin, University of Texas. PhD.

Halliday, F. (2000). Nation and Religion in the Middle East. Boulder, CO, Lynne Rienner.

Hoover, R. (2006). Hasidic population grows, Jewish politics may shift right. University of Florida News

Hout, M., A, Greeley, et al. (2001). "The Demographic Imperative in Religious Change in the United States." American Journal of Sociology 107(2): 468-500.

Hunter, J. (1991). Culture Wars: The Struggle to Define America. New York, Basic Books.

Islamonline (2005). UK Mosque Goers to Double Church Attendance: Study Islamonline.net.

Jackson, R., N. Howe, et al. (2008). The graying of the great powers : demography and geopolitics in the 21st century. Washington, D.C., Center for Strategic and International Studies. 
Jenkins, P. (2007). God's continent : Christianity, Islam, and Europe's religious crisis. Oxford ; New York, Oxford University Press.

Johnson, T. M. and D. B. Barrett (2004). "Quantifying alternate futures of religion and religions." Futures 36: 947-960.

Karim, M. (2005). Islamic Teachings on Reproductive Health. Islam, the State and Population. G. Jones and M. Karim. London, Hurst and Co.: 40-55.

Kaufmann, E. (2007). Sacralisation by Stealth: Demography, Religion and Politics in Europe. London, JPR (Institute for Jewish Policy Research).

Kaufmann, E. (2008). "The End of Secularisation in Europe?: A Demographic Perspective" Working Paper.

Kaufmann, E., A. Goujon, et al. (forthcoming). "The Next American Voter: the Political Demography of American Partisanship" Working Paper.

Kepel, G. (2002). Jihad: The Trail of Political Islam. London, Tauris.

King, L. (2002). "Demographic Trends, Pronatalism, and Nationalist Ideologies in the late Twentieth Century." Ethnic and Racial Studies 25(3): 367-389.

Kraushaar, J. (2007). The Secret Behind a Rocker's Election to Congress: Hasidim The Jewish Daily Forward.

Lesthaeghe, R. and L. Neidert (2006). The "Second Demographic Transition" in the US: Spatial Patterns and Correlates, PSC Research Report

Lichtenstein, H. A. (1981). "The Ideology of Hesder: The View From Yeshivat Har Etzion" Tradition-a Journal of Orthodox Jewish Thought 19(3 (Fall)).

Longman, P. (2005). The Empty Cradle: How Falling Birthrates Threaten World Prosperity and What to do About it. New York, N.Y, Basic Books.

Lutz, W., V. Skirbekk, et al. (2006). The Low Fertility Trap Hypothesis:

Forces that may lead to further postponement and fewer births in Europe. Political Demography: Ethnic, National and Religious Dimensions. LSE, London.

Martin, D. (2001). Pentecostalism: the World their Parish. Oxford, Blackwell.

Mearsheimer, J. J. and S. M. Walt (2006). The Israel Lobby and U.S. Foreign Policy. KSG Faculty Research Working Paper Series, John F. Kennedy School of Government, Harvard University. 
Moaddel, M., S. Karabenick, et al. (2005). Youth, Emotional Energy, and Political Violence: The Cases of Egypt and Saudi Arabia Survey, Association of Religion Data Archives (ARDA).

Morgan, S. P., S. Stash, et al. (2002). "Muslim and non-Muslim differences in female autonomy and fertility: Evidence from four Asian countries." Population and Development Review 28(3): 515-538.

Moulasha, K. and G. R. Rao (1999). "Religion-specific differentials in fertility and family planning." Economic and Political Weekly 34(42-43): 3047-3051.

Munson, Z. (2001). "Islamic mobilization: Social movement theory and the Egyptian Muslim brotherhood." Sociological Quarterly 42(4): 487-510.

NAF (2008) Violence and disruption statistics: Incidents of violence \& disruption against abortion providers in the U.S. \& Canada (National Abortion Federation)

Pape, R. A. (2005). Dying to win: the strategic logic of suicide terrorism. New York, Random House.

Pew Forum on Religion and Public Life (2006). Religion and Public Life: A Faith-Based Partisan Divide, special report. Washington, DC, Pew Center, January 2006.

Regnier-Loilier, A. and F. Prioux (2008). Does religious practice influence fertility behaviour in France? European Population Conference (EPC). Barcelona.

Roof, W. C. and W. McKinney (1987). American Mainline Religion: Its Changing Shape and Future. New Brunswick, Rutgers University Press.

Skirbekk, V. (2009). "Human fertility and survival across space and time." World Population Program, IIASA, Working Paper.

Skirbekk, V., A. Goujon, et al. (forthcoming). Secularism, Fundamentalism or Catholicism?, IIASA Working Paper

Slack, J. A. and R. Doyon (2001). "Population dynamics and Susceptibility for Ethnic Conflict: the case of Bosnia and Herzegovina." Journal of Peace Research 38(2): 139161.

Stark, R. (1996). The Rise of Christianity: a Sociologist Reconsiders History. Princeton, N.J.

Surkyn, J. and R. Lesthaeghe (2004). "Value Orientations and the Second DemographicTransition (STD) in Northern, Western and Southern Europe: An Update." Demographic Research Special Collection 3: Article 3. 
Tait, R. (2006). 'Ahmadinejad Urges Iranian Baby Boom to Challenge West'. Guardian.

Toft, M. (2002). "Differential Demographic Growth in Multinational States: The Case of Israel's Two-Front War." Review of International Affairs Fall.

Toft, M. and T. Shah (2006). "Religion's Flame Burns Brighter Than Ever." Baltimore Sun.

van de Kaa, D. (1987). "Europe's Second Demographic Transition." Population Bulletin 42(1): 1-57.

Wattenberg, B. (2005). Fewer: How the New Demography of Depopulation will Shape our Future. Chicago, Ivan R. Dee.

Westoff, C. F. and T. Frejka (2007). "Religiousness and fertility among European Muslims." Population and Development Review 33(4): 785-+.

Westoff, C. F. and E. Jones (1979). "The End of "Catholic" Fertility." Demography 16(2): 209-217.

Wise, Y. (2007). Majority of Jews will be Ultra-Orthodox by 2050. University of Manchester press release.

Wuthnow, R. (1989). The Struggle for America's Soul: Evangelicals, Liberals and Secularism. Grand Rapids, Mich Eerdmans.

Yavuz, S. (2005). "Fertility transition and the progression to third birth in Turkey " MPIDR Working Paper.

Zakaria, F. (1997). "The Rise of Illiberal Democracy." Foreign Affairs 76(6): 22-43.

Zubaida, S. (2004). "Islam and Nationalism: continuities and contradictions." Nations \& Nationalism 10(4): 407-420.

\footnotetext{
${ }^{1}$ By secular (and secularization), I mean those who a) seek to separate the political sphere from the influence of religious authority; and b) in their private life, do not regularly attend places of religious worship or believe in the sacredness of a particular religious belief system. See Bruce 2002 for the distinction between public and private secularism.

${ }^{2}$ Many ultra-Orthodox Jews have come to embrace Zionism, though a minority remain anti-Zionist.

${ }^{3}$ For example, the WCD suggests that as many as a third of Britons are charismatic, Pentecostal or evangelical Christians in a country where church attendance is less than 12 percent. The Pew study presents data showing the total fertility rate (TFR) of India at 1.4 and Kenya at 2.5, both severe underestimates.

${ }^{4}$ This was confirmed in multivariate tests.

${ }^{5}$ Of course, Kurds and tend to be more religious than average, so a religious effect may operate indirectly.

${ }^{6}$ Religiosity was significant at the .05 level, but only barely so $(\mathrm{t}=2.04)$. Marital status and education levels dominated the model.

${ }^{7}$ Total fertility rate, by contrast, did not come up significant in this model, even with the variable for proportion aged over 65 removed.
} 
${ }^{8}$ The question reads: 'Think about what should change to make your country a better place to live, and please tell us if you agree strongly, agree, disagree, or disagree strongly with the following. Saudi Arabia will be a better society: If the number of children born to families declined.

1) Agree strongly, 2) Agree, 3) Disagree, 4) Strongly disagree, 9) DK.' (ARDA 2005 Codebook)

${ }^{9}$ Now, I would like to know your views about a good government. Which of these traits should a good government have? It should implement only the laws of the Shari'a. 1) Very important, 2) Important, 3) Somewhat important, 4) Least important, 5) Not important, 9) NA.'

${ }^{10} \mathrm{I} \mathrm{m}$ going to describe various types of political systems and ask what you think about each as a way of governing this country. For each one, would you say it is a very good, fairly good, fairly bad or very bad way of governing this country? Having an Islamic government, where religious authorities have absolute power. 1) Very good, 2) Fairly good, 3) Fairly bad, 4) Very bad, 9) DK'. '(ARDA 2005 Codebook)

${ }^{11}$ The data seem to show that extreme Islamo-skeptics are somewhat more supportive of pronatalism, but the numbers in these categories were so small as to render them unreliable. 